\title{
Host-Guest Engineering of Layered Double Hydroxides towards Efficient Oxygen Evolution Reaction: Recent Advances and Perspectives
}

\author{
Jianming $\mathrm{Li}^{2,+}$, Shan Jiang ${ }^{1,+}$, Mingfei Shao ${ }^{1, *(1)}$ and Min Wei ${ }^{1}$ \\ 1 State Key Laboratory of Chemical Resource Engineering, Beijing University of Chemical Technology, \\ Beijing 100029, China; jiangshan3_3@163.com (S.J.); weimin@mail.buct.edu.cn (M.W.) \\ 2 Petroleum Geology Research and Laboratory Center, Research Institute of Petroleum Exploration \& \\ Development (RIPED), PetroChina, Beijing 100083, China; lijm02@petrochina.com.cn \\ * Correspondence: shaomf@mail.buct.edu.cn \\ + These authors contribute equally to this work.
}

Received: 29 March 2018; Accepted: 25 April 2018; Published: 17 May 2018

\begin{abstract}
Electrochemical water splitting has great potential in the storage of intermittent energy from the sun, wind, or other renewable sources for sustainable clean energy applications. However, the anodic oxygen evolution reaction (OER) usually determines the efficiency of practical water electrolysis due to its sluggish four-electron process. Layered double hydroxides (LDHs) have attracted increasing attention as one of the ideal and promising electrocatalysts for water oxidation due to their excellent activity, high stability in basic conditions, as well as their earth-abundant compositions. In this review, we discuss the recent progress on LDH-based OER electrocatalysts in terms of active sites, host-guest engineering, and catalytic performances. Moreover, further developments and challenges in developing promising electrocatalysts based on LDHs are discussed from the viewpoint of molecular design and engineering.
\end{abstract}

Keywords: layered double hydroxide; oxygen evolution reaction; active site; water splitting

\section{Introduction}

Electrochemical water splitting holds great promise for clean energy resources and has aroused broad study interest in recent years [1-5]. Among all the studies, the development of electrocatalysts for the anode oxygen evolution reaction (OER) is one of the key issues to decrease the overpotential of practical water splitting due to its sluggish four-electron process [6-10]. It is well-known that ruthenium and iridium oxides demonstrate high activity for water oxidation in acid and alkaline electrolytes, respectively [11,12]. However, an efficient alternative is still needed because of the high cost and scarcity of noble metal-based catalysts, which is difficult to meet the large-scale applications. Recently, various transition metal compounds (e.g., oxides, [13-15], hydroxides [16-20], and phosphides [21-24]) have emerged as a new family of OER electrocatalysts. Especially, the homogeneous mixed-transition-metal compounds without phase segregation have been reported with higher OER activity, probably owing to the effectively modulated 3d electronic structures. For instance, NiFe-based electrocatalysts have become a kind of dazzling material attributed to their high OER activity, since first investigated by Corrigan in the 1980s [25], and significantly promoted by Dai in 2013 [26].

Layered double hydroxides (LDHs) are a large class of two-dimensional (2D) intercalated materials which can be described by the general formula $\left[\mathrm{M}^{\mathrm{II}}{ }_{1-x} \mathrm{M}^{\mathrm{III}}{ }_{x}(\mathrm{OH})_{2}\right]^{z+}\left(\mathrm{A}^{n-}\right)_{z / n} \cdot y \mathrm{H}_{2} \mathrm{O}\left(\mathrm{M}^{\mathrm{II}}\right.$ and $\mathrm{M}^{\mathrm{III}}$ are divalent and trivalent metals respectively; $\mathrm{A}^{n-}$ is the interlayer anion compensating for the positive charge of the brucite-like layers) [27-29]. Recently, LDHs, especially NiFe-LDH, are believed to be 
one of the ideal and promising electrocatalysts for water splitting due to their excellent OER activity, high stability in basic conditions, and low cost [30-34]. To date, various LDHs, as well as their nanocomposites, have been synthesized for better OER performances. For example, the design and synthesis of LDHs/conducting-material composites can overcome the intrinsically poor conductivity of LDHs and provide a rapid transport of electrons/ions [35-42]. To improve the intrinsic activity, the role of host transition layers and guest interlayer anions in increasing the OER activity have also been considered [43-49]. Boettcher et al. found that the incorporation of Fe shows a more than 30-fold increase in conductivity, as well as a partial-charge transfer activation effect of Fe to $\mathrm{Ni}$ sites [50]. Jin et al. detected the presence of $\mathrm{Fe}^{\mathrm{IV}}$ in NiFe-LDH during steady-state water oxidation by using operando Mössbauer spectroscopy [51], which has important implications for stabilizing the $\mathrm{NiOOH}$ lattice. Although, with this progress, how to determine the real active sites, as well as how to rationally design much more efficient electrocatalysts based on LDHs, still remains highly desirable and challenging.

Along with the increasing development of LDH-based OER catalysts, some important reviews on different aspects have already been reported. For example, Dai et al. first gave a mini review about NiFe-based materials (including alloys, oxides, and hydroxides) for OER in 2015 [52], where the related mechanism and applications have been briefly discussed. Our group summarized the development of LDH materials for electrochemical energy storage and conversion [53], in which the OER applications have been discussed from the viewpoint of electrode materials design. Strasser et al. further published a review article focusing on the progresses of NiFe-based (Oxy)hydroxide catalysts [54]. Other excellent reviews also mentioned LDH-based OER electrocatalysts, including the perspective on the OER activity trends and design principles based on transition metal oxides and (oxy)hydroxides by Boettcher et al., [55] and nanocarbon-based electrocatalysts summarized by Zhang et al., [56].

Nevertheless, the discussion on the LDH-based OER catalysts from the viewpoint of their supramolecular intercalated structures is seldom considered. In this review, we will focus on the roles of the host layer and guest interlayer anions in the OER performances of LDHs. The recent advances in the host layer designs will be first discussed in order to provide a systematic digestion of previous achievements in the unveiling of the active nature of metal ions in promoting water oxidation. The interlayer anions also play an indispensable synergistic effect, which will be demonstrated in the next discussion. We also hope to display future efficient OER electrocatalysts based on LDHs from the molecular design and engineering.

\section{The Engineering of Host Layer}

\subsection{The Role of Host Layer Metal Ions}

Electrochemical water splitting under both acidic and alkaline conditions has been studied for more than a half century as a means of storing clear energy. It is noted that OER is a four electron-proton coupled reaction, while hydrogen evolution reaction (HER) is only a two electron-transfer reaction, which implies that a higher energy is required for OER process to overcome the reaction barrier. In the past decades, nickel-based electrodes have been widely used as anode catalysts for alkaline water splitting due to the merits of earth-abundance, high activity, and good stability [57-61]. Corrigan found that a low concentration of iron impurity in nickel oxide increased the OER kinetics obviously [25]. Moreover, the oxygen evolution overpotential for the sample with iron impurities of $10-50 \%$ in the nickel oxide is substantially lower than that of either nickel oxide or iron oxide. Although without a clear understanding about this interesting phenomenon, a synergetic effect between nickel and iron species for catalyzing the OER process has been rationally assumed. This inspired the intensive investigations to study various NiFe mixed compounds and the catalytic roles for $\mathrm{Ni}$ and $\mathrm{Fe}$ in order to obtain better OER electrocatalysts. As a family of typical two-dimensional inorganic materials, LDHs consist of brucite-like $\left[\mathrm{Mg}(\mathrm{OH})_{2}\right]$ host nanosheets with edge-sharing metal- $\mathrm{O}_{6}$ octahedra (lateral 
particle size ranging from nanometer to micrometer-scale). The easy tunability of metal ions without altering the structure, as well as anion exchange properties of LDHs, make them interesting alternatives for applications in electrochemistry. Bell et al. synthesized ( $\mathrm{Ni}, \mathrm{Fe})$ oxyhydroxides across the entire composition range (Figure 1a,b) [62]. It was found that the addition of $25 \% \mathrm{Fe}$ to $\mathrm{Ni}(\mathrm{OH})_{2}$ results in up to a 500-fold higher OER current density compared to pure $\mathrm{Ni}$ and Fe oxyhydroxide films at the overpotential of $0.3 \mathrm{~V}$. Zhang et al. also investigated the effect of different $\mathrm{Ni} / \mathrm{Fe}$ molar ratios to their OER performances [63]. It was found that moderate metal substitution into the host hydroxide framework (Fe into Ni or Ni into $\mathrm{Fe}$ ) substantially enhanced the OER activity with a decrease of both the Tafel slope and overpotential. To further accurately control the Fe content, Boettcher et al. developed a method for purification of $\mathrm{KOH}$ electrolyte by using precipitated bulk $\mathrm{Ni}(\mathrm{OH})_{2}$ to absorb Fe impurities [50]. As a result, no significant OER current is observed until $>400 \mathrm{mV}$ overpotential for $\mathrm{Ni}(\mathrm{OH})_{2}$ films aged in purified $\mathrm{KOH}$ electrolyte. The excellent conductivity of electrocatalysts is important to achieve a fast charge transfer through the catalyst film with a negligible potential drop. To study the conductivity trends of LDHs with different metal ion ratios, various NiFe-LDH have been synthesized by using the purified $\mathrm{KOH}$ electrolyte. The conductivity measurement showed that all NiFe-LDH films have low conductivities at low potential, while a sharp increase along with the Ni oxidation (Figure 1c). The NiFe-LDH films with Fe content range from $5 \%$ to $25 \%$ gives $\sigma \approx 3.5$ to $6.5 \mathrm{mS} \mathrm{cm}^{-1}$, significantly higher than that of Fe-free film $\left(\sigma \approx 2.5 \mathrm{mS} \mathrm{cm}^{-1}\right)$, indicating that $\mathrm{Fe}$ increases the conductivity of $\mathrm{NiOOH}$. Figure $1 \mathrm{~d}$ compares the turnover frequency (TOF) as a function of the thickness for Fe-free $\mathrm{NiOOH}$ and $\mathrm{Ni}_{0.75} \mathrm{Fe}_{0.25} \mathrm{OOH}$ deposited on two kinds of substrate (Au and GC). It is concluded that Fe enhances the activity of $\mathrm{NiOOH}$ through a $\mathrm{Ni}-\mathrm{Fe}$ partial-charge-transfer activation process.
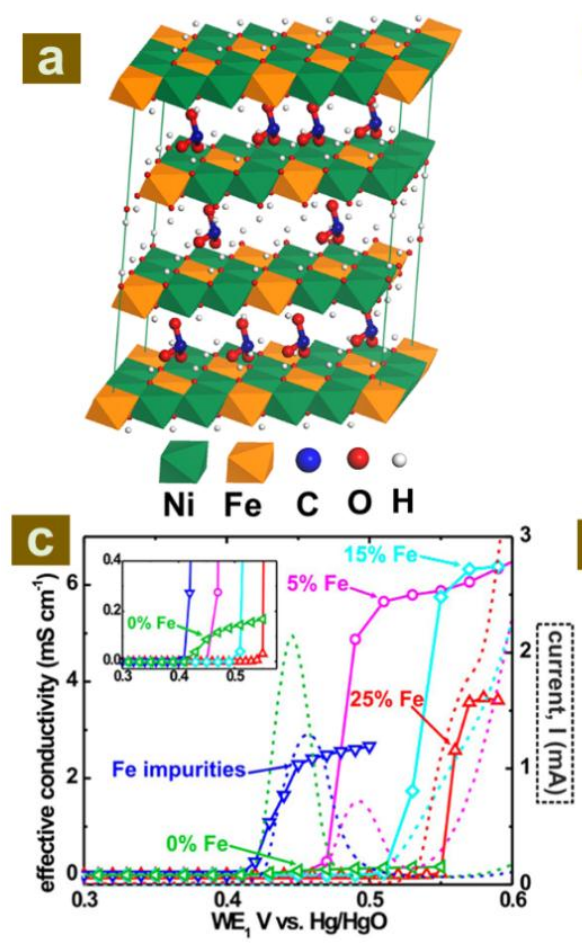
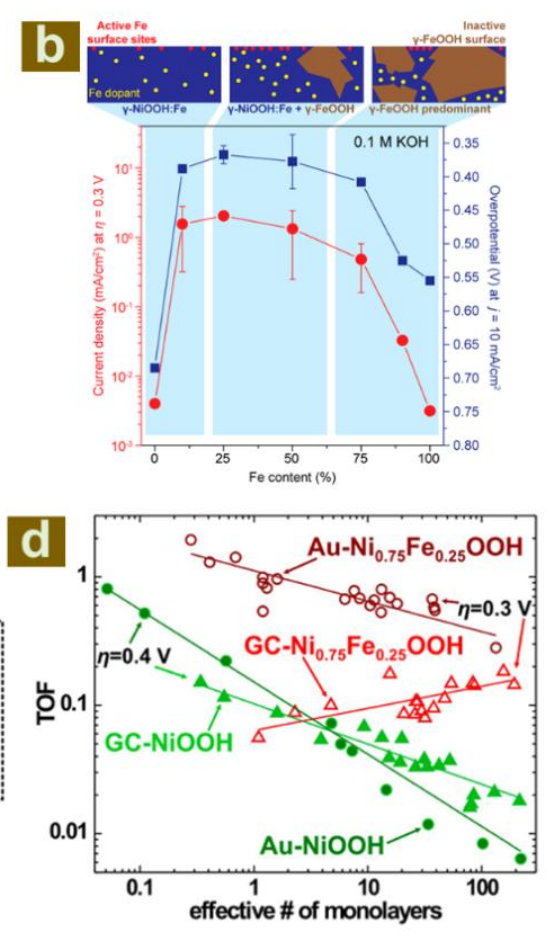

Figure 1. (a) Schematic illustration of the crystal structure of NiFe-LDH. (b) Measured OER activity of mixed $\mathrm{Ni}-\mathrm{Fe}$ catalysts as a function of Fe content. Reproduced from [62], Copyright American Chemical Society, 2014. (c) Conductivity data for the $\mathrm{Ni}_{1-x} \mathrm{Fe}_{x} \mathrm{OOH}$ with various Fe content. (d) TOFs as a function of film thickness for Fe-free $\mathrm{NiOOH}$ and $\mathrm{Ni}_{0.75} \mathrm{Fe}_{0.25} \mathrm{OOH}$. Reproduced from [50], Copyright American Chemical Society, 2014. 
In addition to the enhanced conductivity, the catalytically-active metal redox state of the $\mathrm{NiFe}$-based catalyst has remained under debate. It has long been assumed that $\mathrm{Ni}$ is the reactive site for water oxidation in NiFe oxide electrocatalysts on the basis of the high activity of Ni oxide electrocatalysts. For example, Strasser et al. found that the Fe centers consistently remain in the $\mathrm{Fe}^{\mathrm{III}}$ state regardless of potential and composition [64], which was determined by operando differential electrochemical mass spectrometry (DEMS) and X-ray absorption spectroscopy (XAS) under OER conditions. On the other hand, $\mathrm{Ni}^{\mathrm{IV}}$ at $\mathrm{Fe}$ content below $4 \%$ has been detected under catalytic conditions, while $\mathrm{Ni}$ atoms stabilized in a low-valent oxidation state when further increasing the content of Fe. This difference in metal valent states mainly depends on the rate of water oxidation-metal-reduction $\left(k_{\mathrm{OER}}\right)$ and metal oxidation $\left(k_{\mathrm{Mox}}\right)$ (Figure $\left.2 \mathrm{a}\right)$. The lower $k_{\mathrm{Mox}} / k_{\mathrm{OER}}$ ratio reflects a dramatically increased rate constant of water oxidation $\left(k_{\text {Mox }}\right)$, which may exceed the rate of the metal oxidation $\left(k_{\mathrm{OER}}\right)$. It concluded that high catalytic OER activity of the mixed $\mathrm{Ni}-\mathrm{Fe}$ catalysts demonstrate a sharply-decreased $k_{\mathrm{Mox}} / k_{\mathrm{OER}}$ ratio. They further give a catalytic OER cycle (Figure $2 b$ ), where the buildup of oxidation equivalents from $\mathrm{Ni}^{\mathrm{II}}$ to $\mathrm{Ni}^{\mathrm{IV}}$ sites is followed by the $\mathrm{O}-\mathrm{O}$ bond formation with the subsequent release of molecular oxygen. However, there is substantial evidence from X-ray absorption and Mössbauer experiments that $\mathrm{Ni}^{\mathrm{IV}}$ and $\mathrm{Fe}^{\mathrm{IV}}$ are both found in $\mathrm{NiFe}-\mathrm{LDH}$ at OER potentials during different studies $[51,65,66]$. Recently, Stahl et al. detected the $\mathrm{Fe}^{\mathrm{IV}}$ species (up to $21 \%$ of the total Fe) during steady-state water oxidation on NiFe-LDH [51]. The stable presence of $\mathrm{Fe}^{\mathrm{IV}}$ can be ascribed to the increased electron-donating ability of the $\pi$-symmetry lone pairs of the bridging oxygen atoms between $\mathrm{Ni}$ and Fe (Figure 2c,d), which makes the $\mathrm{NiOOH}$ lattice a more stable environment for high-valent metal ions.
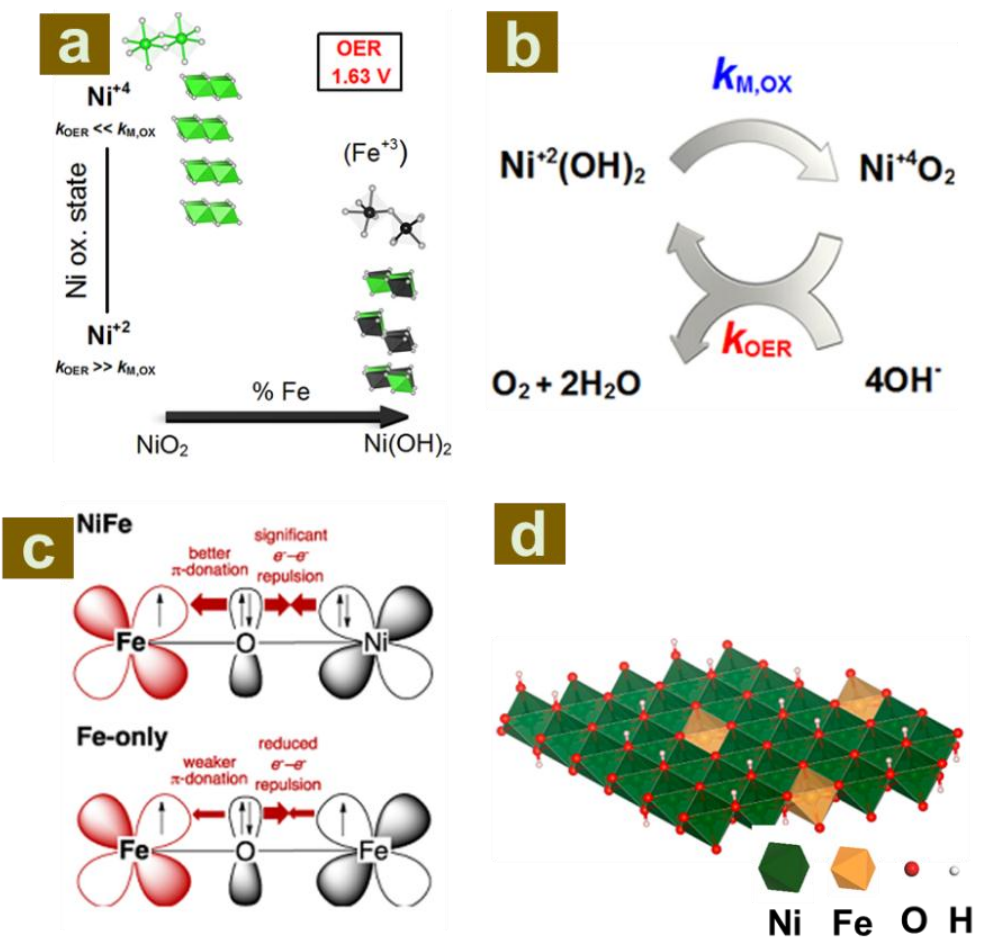

Figure 2. (a) XAS-derived structural motifs prevalent during OER catalysis at high and intermediate Ni-content. (b) Simplified scheme of the electrochemical water splitting cycle. Reproduced from [64], Copyright American Chemical Society, 2016. (c) Electronic effects that could rationalize the observation of $\mathrm{Fe}^{\mathrm{IV}}$ in $\mathrm{NiFe}$, but not Fe oxide catalysts. (d) Schematic representation of a layered $\mathrm{NiOOH}$ lattice containing Fe ions in different sites (orange-brown). Reproduced from [51], Copyright American Chemical Society, 2015. 
Based on the previous results and the above discussion, the brief conclusions can be obtained: (1) iron impurity in nickel oxide and hydroxide significantly promote the electrocatalytic water oxidation, and suitable $\mathrm{Ni} / \mathrm{Fe}$ ratio (from 2:1 to 4:1) can further improve OER activity; (2) the conductivity of $\mathrm{Ni}(\mathrm{OH})_{2} / \mathrm{NiOOH}$ increases when combined with iron element at a suitable level (from $5 \%$ to $25 \%$ ) due to the Fe-induced charge transfer; (3) the $\mathrm{Ni}$ or Fe as active sites have both been reported, which has been verified by the detected high valence states of $\mathrm{Ni}^{\mathrm{IV}}$ or $\mathrm{Fe}^{\mathrm{IV}}$, while the presence of high valence metal ions probably depends on the metal and water oxidation rate. Therefore, different metal ions introduced into the LDH host layer induces a varied chemical and electronic environment, which thereby varied their OER performances. In addition to NiFe-LDH, other LDHs with various host metal ions (e.g., $\mathrm{NiCo}, \mathrm{NiMn}, \mathrm{ZnCo}$, and $\mathrm{CoAl}$ ) have been demonstrated as OER electrocatalysts (Figure 3) [67-91]. However, their activity is still lower than that of NiFe-LDH.

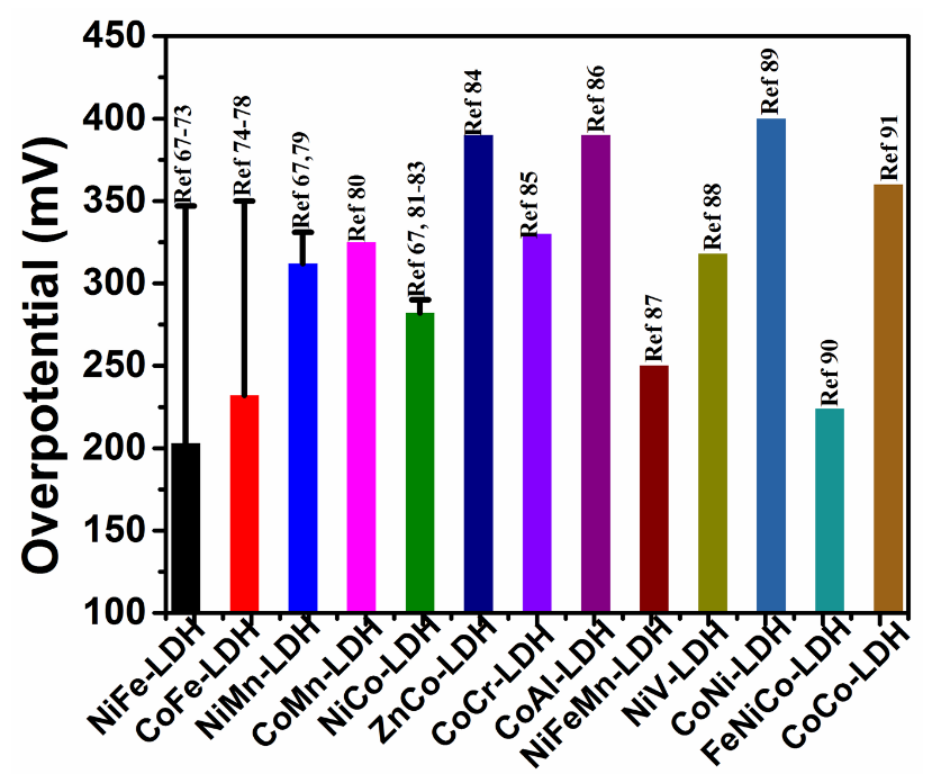

Figure 3. Overpotentials required at $j=10 \mathrm{~mA} \mathrm{~cm}^{-2}$ for various LDHs (the error bars indicate a range of overpotentials).

\subsection{The Engineering of LDH Host Layers}

\subsubsection{The Exfoliation of LDHs}

The electrochemical properties of an electrocatalyst are affected by its nanostructures [92-95]. For instance, the atomically-thin 2D inorganic materials usually demonstrate unique properties compared with their bulk counterparts [96-100]. LDHs are composed of atomically-thick positive brucite-like host layers and interlayer anions. In practice, LDHs are stacked with several layers, which limits their electrochemical performances due to the inaccessibility to the inner surfaces of the host layers. In the past decades, ultrathin LDH nanosheets with atomic thickness have been synthesized by both "bottom-up" and "top-down" approaches [101-106], which provide opportunities in maximizing the utility of the layers and improving their physicochemical properties (e.g., specific surface area and conductivity). Particularly, the "top-down" delamination method is the most widely developed for producing thin $\mathrm{LDH}$ platelets with a thickness of a few atomic layers. Hu et al. first used the exfoliation strategy to promote the OER performances of LDHs [91]. The CoCo, NiCo, and NiFe-LDH with $\mathrm{Br}^{-}$ anions are prepared as representative LDH materials, which are exfoliated into single-layer nanosheets in the formamide solution. The OER current densities at an overpotential of $300 \mathrm{mV}$ were enhanced by 2.6-, 3.4-, and 4.5-fold upon exfoliation of $\mathrm{CoCo}, \mathrm{NiCo}$, and NiFe-LDH, respectively, compared with their bulk materials. Additionally, the water oxidation activity has the order of $\mathrm{NiFe}>\mathrm{NiCo}>\mathrm{CoCo}$ 
for both exfoliated nanosheets and bulk LDHs. Following this work, they further synthesized ultrathin CoMn-LDH nanoplatelets ( $3-5 \mathrm{~nm}$ ) by a coprecipitation method [80], which gives a current density of $42.5 \mathrm{~mA} \mathrm{~cm}{ }^{-2}$ at $\eta=350 \mathrm{mV}$. This value is about 7.6, 22.5, and 2.8 times higher than that of $\mathrm{Co}(\mathrm{OH})_{2}+\mathrm{Mn}_{2} \mathrm{O}_{3}$, spinel $\mathrm{MnCo}_{2} \mathrm{O}_{4+\delta}$, and $\mathrm{IrO}_{2}$, respectively.

Exfoliated ultrathin LDH nanosheets display enhanced active site exposure. However, the LDHs' exfoliation in liquid usually suffers from strong adsorption of solvent molecules, as well as the restacking when removing the surface solvent $[107,108]$. In addition to liquid exfoliation of LDHs, Wang et al. developed an efficient strategy for the exfoliation of LDHs into stable and clean ultrathin nanosheets by plasma etching [78]. The high-energy plasma destroys the ionic bonds and hydrogen bonds in the interlayers of the bulk LDHs, which interrupted the host-guest charge balance and separated the brucite-like host layers from each other. For instance, the thickness of CoFe-LDH have been successfully decreased from $\sim 20 \mathrm{~nm}$ to $0.6 \mathrm{~nm}$ by subjecting bulk CoFe-LDH to Ar plasma etching for $60 \mathrm{~min}$. Moreover, the coordination number of the $\mathrm{Co}-\mathrm{O}_{\mathrm{OH}}$ octahedra is lower than that in the bulk CoFe-LDH, suggesting the presence of oxygen vacancies (VO). The as-prepared LDH ultrathin nanosheets demonstrate much-improved OER performance with a low overpotential of $266 \mathrm{mV}$ at $10 \mathrm{~mA} \mathrm{~cm}{ }^{-2}$. Recently, they further reported the exfoliation of CoFe-LDH by a water plasma-assisted strategy (Figure 4a) [109], which was accompanied with the formation of multi-vacancies, including $\mathrm{O}, \mathrm{Co}$, and Fe vacancies. The as-exfoliated ultrathin LDHs nanosheets with multi-vacancies show significantly promoted electrocatalytic activity for water oxidation. As shown in Figure 4b, water-plasma exfoliated CoFe-LDH nanosheets just require a low overpotential of $290 \mathrm{mV}$ to reach $10 \mathrm{~mA} \mathrm{~cm}{ }^{-2}$ while the pristine CoFe-LDH need an overpotential of $332 \mathrm{mV}$. Therefore, the effective exfoliation, as well as the defect introduction, both promotes the OER activity of LDHs.
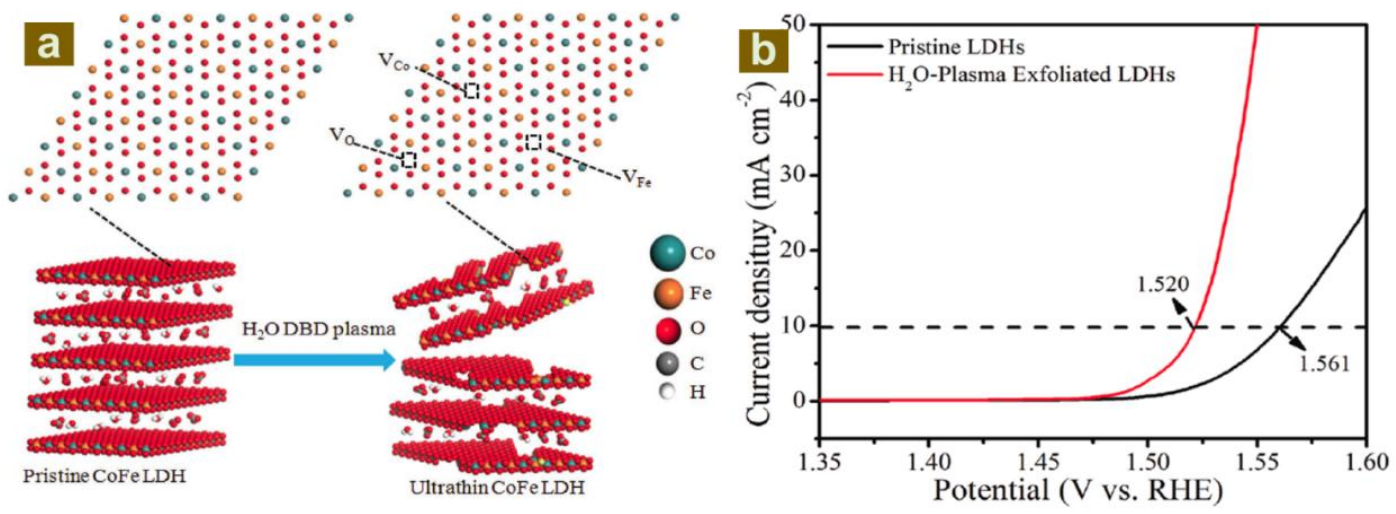

Figure 4. (a) Schematic illustration of the water-plasma-enabled exfoliation of CoFe-LDH nanosheets in a dielectric barrier discharge (DBD) plasma reactor. (b) Linear scan voltammogram (LSV) curves for OER on pristine CoFe-LDH and the water-plasma exfoliated CoFe-LDH nanosheets. Reproduced from [109]. Copyright Wiley, 2017.

\subsubsection{Construction of LDH Nanoarrays}

LDH nanosheet arrays (NSAs), that have highly-dispersed nanoplatelets, well-uniformed orientation, and improved conductivity compared with LDH powdered samples, have been recently constructed as efficient OER electrocatalysts [110-118]. Various LDH NSAs have been perpendicularly grown on the surface of conducting substrates (metals [115], conducting glasses [116], carbon fibers [117], and papers [118]) by in situ procedures. One of the most effective methods for the fabrication of LDH NSAs is the hydrothermal process [119,120]. To design an highly-active OER electrocatalyst, Huang et al. reported a single-crystalline NiFe-LDH NSA array on a Ni foam with the assistance of a direction agent of $\mathrm{NH}_{4} \mathrm{~F}$ [120]. The top and cross-sectional Scanning Electron Microscope (SEM) images of NiFe-LDH NSAs reveal a highly-oriented flake array nanostructure that is in vertical contact with the substrate (Figure 5a,b), with an edge length of 1-3 $\mu \mathrm{m}$ and a uniform thickness of less 
than $20 \mathrm{~nm}$. The high-resolution transmission electron microscopy (HRTEM) image and corresponding selected area electron diffraction (SAED) pattern illustrate a single crystal phase of LDH (Figure 5c). The NiFe-LDH NSAs exhibits superior OER activity compared with the coated NiFe-LDH film, as well as a $\mathrm{RuO}_{2}$ film electrode, achieving the overpotentials of $210 \mathrm{mV}, 240 \mathrm{mV}$, and $260 \mathrm{mV}$ at the current densities of 10, 50, and $100 \mathrm{~mA} \mathrm{~cm}^{-2}$, respectively. Moreover, it is found that the single-crystalline $\mathrm{NiFe}-\mathrm{LDH}$ arrays display smaller overpotentials than that of the reported amorphous NiFe materials and other analogous LDH-based materials. The hexamethylenetetramine $\left(\mathrm{C}_{6} \mathrm{H}_{12} \mathrm{~N}_{4}\right)$ also can be used as a direct agent to prepare vertically-aligned LDH NSAs [72]. For example, the NiFe-LDH NSAs grown on the nickel foam were created by an in situ co-precipitation approach using a reaction solution containing $\mathrm{Ni}\left(\mathrm{NO}_{3}\right)_{2}, \mathrm{Fe}\left(\mathrm{NO}_{3}\right)_{3}, \mathrm{C}_{6} \mathrm{H}_{12} \mathrm{~N}_{4}$, and $\mathrm{CH}_{3} \mathrm{OH}$. SEM images of the NiFe-LDH NSAs reveal a three-dimensional (3D) porous architecture with a LDH thickness of about $15 \mathrm{~nm}$. TEM elemental mapping images of as-synthesized NiFe-LDH scratched off nickel foam suggest that $\mathrm{Ni}$, $\mathrm{Fe}$, and $\mathrm{O}$ elements are uniformly distributed over the NiFe-LDH (Figure 5f). The OER performances of LDH@nickel foam (NF) NSAs, $\mathrm{Ni}(\mathrm{OH})_{2} @ \mathrm{NF}$ NSAs, and NF were evaluated in a typical three-electrode electrochemical cell in $1.0 \mathrm{M} \mathrm{KOH}$ solution at room temperature. Figure $5 \mathrm{~g}$ displays the OER polarization curves of LDH@NF, $\mathrm{Ni}(\mathrm{OH})_{2} @ \mathrm{NF}$, and NF. It is clear that NiFe-LDH@NF demonstrates the highest OER activity compared with the contrast samples, with the lowest overpotential of $210 \mathrm{mV}$ at $10 \mathrm{~mA} \mathrm{~cm}{ }^{-2}$, which are 88, 110, and $161 \mathrm{mV}$ less than those of NiCo-LDH@NF, Ni(OH) $@ \mathrm{NF}$, and NF, respectively. In addition, the well-uniformed NiFe-LDH NSAs also displays promising HER performances in $1.0 \mathrm{mM} \mathrm{KOH}$ solution with low overpotential of $133 \mathrm{mV}$ at $10 \mathrm{~mA} \mathrm{~cm}{ }^{-2}$. The bi-functional electrocatalysts for OER and HER were further used for the overall water splitting in a two-electrode electrolysis cell (Figure 5h), which just needs a cell voltage of $1.59 \mathrm{~V}$ to give a water splitting current density of $10 \mathrm{~mA} \mathrm{~cm}^{-2}$ in $1.0 \mathrm{M} \mathrm{KOH}$ solution with a scan rate of $2 \mathrm{mV} \mathrm{s}^{-1}$ (Figure 5i). It is found that the nanosheet array architecture has increased the electrochemical surface area, which provides more catalytic active sites and favors the efficient adsorption and transfer of reactants. In addition, the well-ordered arrays also benefit the gas evolution reaction and subsequently enhance the electrocatalytic activity [121].

In addition to direct co-precipitation, the template-directed method is another effective strategy for the synthesis of LDH arrays as efficient OER electrocatalysts [122-124]. Sun et al. develop a two-step hydrothermal method to synthesize hierarchical NiCoFe-LDH NSAs [125]. In this process, $\mathrm{Co}_{2}(\mathrm{OH})_{2} \mathrm{CO}_{3}$ nanowire arrays grown on the $\mathrm{Ni}$ foam were first achieved to provide a Co source and to support the growth of NiCoFe-LDH NSAs in the presence of Fe ${ }^{\mathrm{III}}$ and urea (Figure 6a). The introduction of $\mathrm{Ni}$ in the $\mathrm{LDH}$ can be ascribed to the dissolution of the $\mathrm{Ni}$ foam substrate at a low $\mathrm{pH}$ value $(\mathrm{pH}=1.2)$ due to the hydrolysis of $\mathrm{Fe}^{\mathrm{III}}$ and precipitation of $\mathrm{Ni}^{\mathrm{II}}$ in the solution. The density of the LDH NSAs on the nanowires can be tuned by simply changing the molar amount of $\mathrm{Fe}^{\mathrm{III}}$ during the second hydrothermal step. With a low concentration of Fe $\mathrm{F}^{\mathrm{III}}(0.5 \mathrm{mmol})$, just a few LDH nanoplatelets grew on the nanowires (denoted as H-LDH-0.5, Figure 6b). When the amount of Fe $\mathrm{F}^{\mathrm{III}}$ increased to $1 \mathrm{mmol}$, the density of LDH NSAs around the nanowires clearly increased and the diameter of the individual nanowire@nanoplatelet expanded to $250 \mathrm{~nm}$ (H-LDH-1, Figure 6c). The hierarchical nanoarray architecture benefits the improvement of the electrochemical properties of active materials by exposing more active sites. As a result, a high OER rate of $80 \mathrm{~mA} \mathrm{~cm}^{-2}$ for the H-LDHs could be readily achieved by applying a small overpotential ( $257 \mathrm{mV}$ for H-LDH-1), much better than that of the $\mathrm{Co}_{2}(\mathrm{OH})_{2} \mathrm{CO}_{3}$ nanowire arrays $(420 \mathrm{mV})$ and LDH NPs $(492 \mathrm{mV})$. Zhao et al. fabricated CoFe-LDH NSAs by a solution phase cation exchange method at room temperature by dipping the $\mathrm{Cu}$ foam loaded with $\mathrm{Cu}_{2} \mathrm{O}$ nanoarrays into an aqueous solution of $\mathrm{CoCl}_{2}$ and $\mathrm{FeCl}_{2}$ (Figure 6d) [74]. In this process, $\mathrm{OH}^{-}$was generated in situ along with the etching of $\mathrm{Cu}_{2} \mathrm{O}$ nanowires by $\mathrm{S}_{2} \mathrm{O}_{3}{ }^{2-}$, which then leads to the precipitation of metal ions. The resulting CoFe-LDH NSAs inherited the geometry of the $\mathrm{Cu}_{2} \mathrm{O}$ template (Figure 6e,f). The $\mathrm{Cu}_{2} \mathrm{O}$ nanoarrays show negligible OER activity, while $\mathrm{Co}_{0.70} \mathrm{Fe}_{0.30}-\mathrm{LDH}$ NSAs give an OER onset overpotential as low as $220 \mathrm{mV}$, a small Tafel slope at $62.4 \mathrm{mV} \mathrm{dec}^{-1}$, as well as excellent long-term durability (>100 h). 

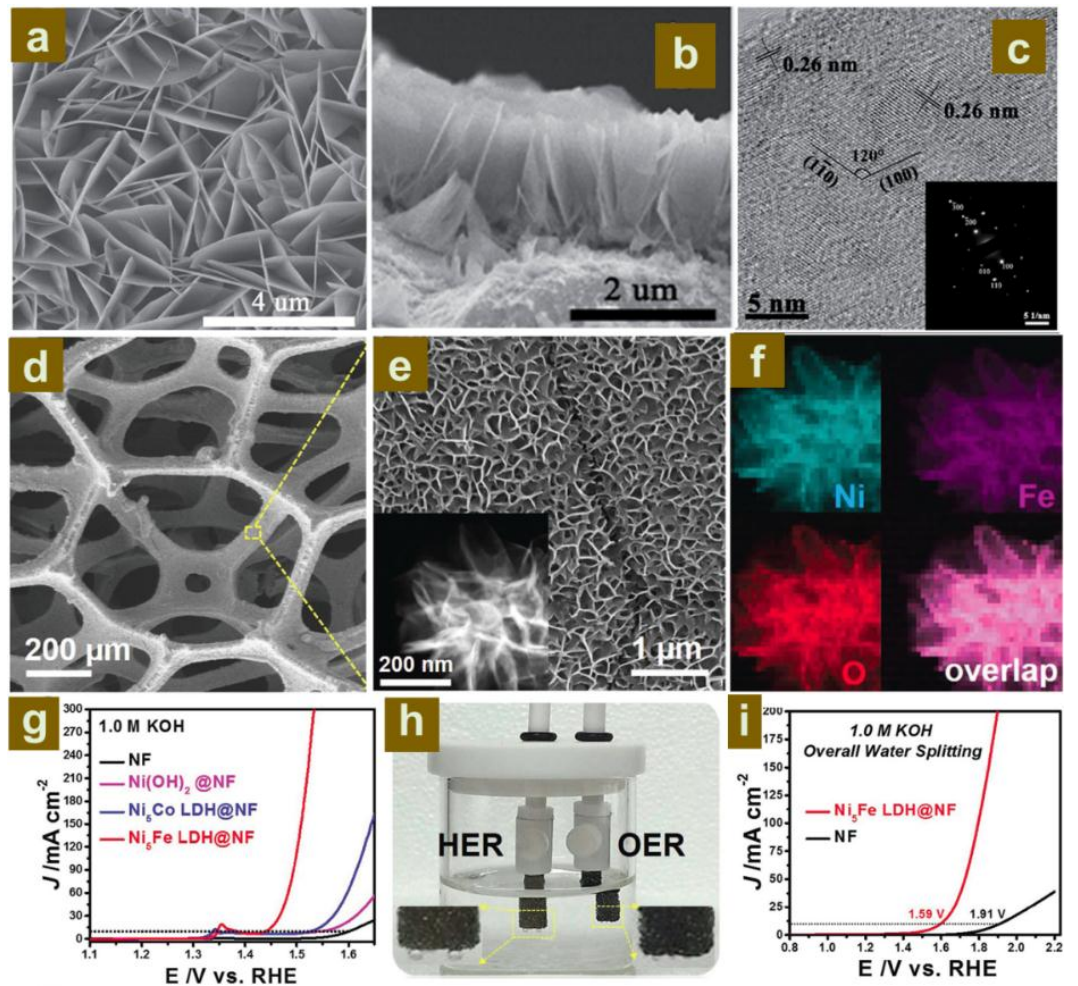

Figure 5. (a) SEM image of NiFe-LDH flakes grown on the nickel foam, and (b) is the corresponding cross-sectional image. (c) HRTEM image and SAED pattern (inset in (c)) of a single NiFe-LDH layer.

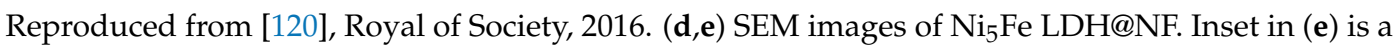
HAADF-STEM image of the $\mathrm{Ni}_{5} \mathrm{Fe}-\mathrm{LDH}$ scratched off NF. (f) TEM elemental mapping images of $\mathrm{Ni}_{5} \mathrm{Fe}$ LDH scratched off NF with blue for $\mathrm{Ni}$, purple for $\mathrm{Fe}$, and red for $\mathrm{O}$. (g) OER polarization curves of $\mathrm{NF}, \mathrm{Ni}(\mathrm{OH})_{2} @ \mathrm{NF}, \mathrm{Ni}_{5} \mathrm{Co}-\mathrm{LDH} @ \mathrm{NF}$, and $\mathrm{Ni}_{5} \mathrm{Fe}-\mathrm{LDH} @ \mathrm{NF}$. (h) Optical images of the $\mathrm{Ni}_{5} \mathrm{Fe}-\mathrm{LDH} @ \mathrm{NF}$ electrode and overall water splitting device. (i) The steady-state polarization curve for overall water splitting of $\mathrm{Ni}_{5} \mathrm{Fe}-\mathrm{LDH} @ \mathrm{NF}$ and NF in a two-electrode configuration. Reproduced from [72], Copyright Wiley, 2017.

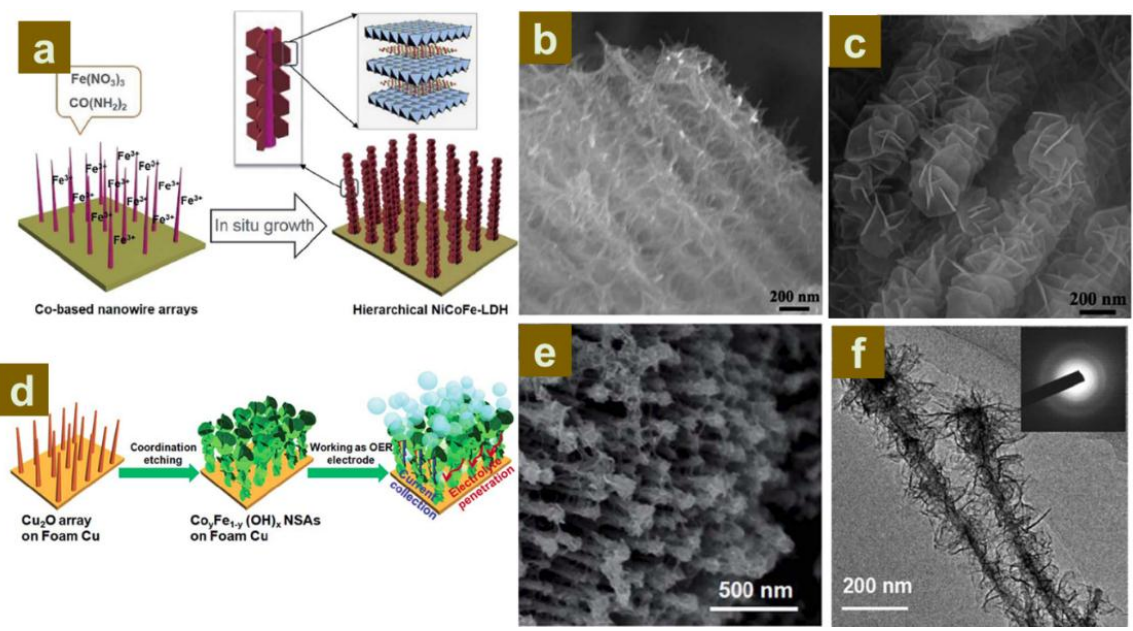

Figure 6. (a) Schematic illustration of the hierarchical NiCoFe-LDH nanoarrays via a two-step hydrothermal method. SEM images of the hierarchical NiCoFe-LDH nanoarrays: (b) H-LDH-0.5; (c) H-LDH-1. Reproduced from [125], Copyright Royal of Society, 2014. (d) Schematic illustration of the fabrication process for CoFe-LDH NSAs. (e) SEM and (f) TEM images of CoFe-LDH NSAs. Reproduced from [74], Copyright Royal of Society, 2017. 
A facile method to prepare electrode materials with the merits of fast and one-pot synthesis on the conducting substrates is a critical step when considering the practical operations. The electrosynthesis approach is often used to fabricate electrochemical active films on conducting materials' surfaces [126-128]. Numerous materials have been developed by using the electrosynthesis process for applications in energy storage and conversion, such as transition metal oxides [129] and hydroxides [130], and conducting polymers [131]. The morphology and thickness of as-synthesized films can be manipulated by monitoring electrochemical variables, such as the potential and coulombic charge. Our group developed an electrochemical approach for the fast, precisely-controllable, and economic fabrication of various Fe-containing LDH hierarchical nanoarrays (Figure 7a) [68]. This electrosynthesis process was achieved by the following proposed reduction reaction on the working electrode: $\mathrm{NO}_{3}{ }^{-}+\mathrm{H}_{2} \mathrm{O}+2 \mathrm{e}^{-} \rightarrow \mathrm{NO}_{2}{ }^{-}+2 \mathrm{OH}^{-}$, in which the resulting $\mathrm{OH}^{-}$leads to the precipitation of LDHs. The whole electrosynthesis process is finished successively within hundreds of seconds at room temperature and the thickness of the LDH NSAs can be controlled by the deposition time. Figure $7 \mathrm{~b}$ shows the SEM image of the as-obtained NiFe-LDH NSAs, where ultrathin $(8 \mathrm{~nm}$ in thickness) and uniform NiFe-LDH platelets were grown perpendicularly to the surface of nickel foam substrate. The TEM image further shows a thin sheet-like nanostructure. In addition, LDHs' NSAs with uniform and homogeneous surface morphology can be synthesized on the foam nickel substrate with different sizes, such as from $2 \mathrm{~cm}^{2}$ to $100 \mathrm{~cm}^{2}$ (Figure $7 \mathrm{~d}$ ). This is further adequate for the fabrication of NiFe-LDH NSAs on other conducting substrates, including conducting cloths and glasses (Figure 7e,f). The OER activity of NiFe-LDH NSAs was further studied, which displays the lowest onset potential of OER current and the highest current density at the same overpotential $(\eta)$ compared with the CoFe- and LiFe-LDH NSAs. Moreover, it shows high energy conversion efficiency from electric energy to chemical energy with a Faradaic efficiency of $99.4 \%$ after a testing period of $10 \mathrm{~min}$. The electrosynthesized NiFe-LDH NSAs also gives significantly long-term stability and the current density of OER remains constant at each given potential after $50 \mathrm{~h}$ of continued measurement. In addition, the electrosynthesis method can be extended to the various micro-substrates, which gives uniform core-shell nanostructures and improved electrochemical properties [132-136].

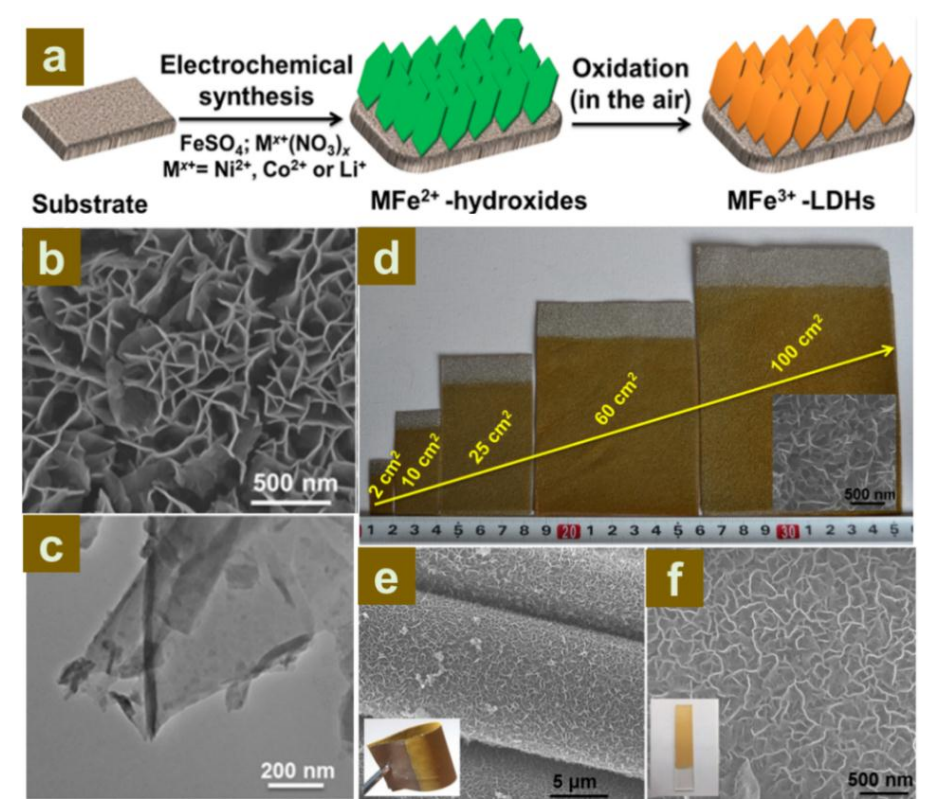

Figure 7. (a) Scheme of the synthetic route to MFe-LDH (M=Co, Ni and Li) NSAs. (b) SEM and (c) TEM image of NiFe-LDH NSAs. (d) Photographs of NiFe-LDH NSAs synthesized on the foam nickel substrates at various scales (inset: the SEM image of NiFe-LDH on $100 \mathrm{~cm}^{2}$ substrate). SEM images for NiFe-LDH nanoplatelet arrays on (e) the conducting cloth and (f) FTO substrate (inset: their corresponding photographs). Reproduced from [68], Copyright Royal of Society, 2015. 


\section{The Engineering of Interlayer Guests}

Various anions can be intercalated into the interlayer of LDHs, which varies their chemical environment of host layers. Layer-by-layer assembly (LBL) of exfoliated LDH nanosheets with different interlayer anions through electrostatic interaction is a good way to introduce different interlayer anions [137-141]. Our group has reported the assembly of well-ordered CoNi-LDH NS/iron porphyrin (Fe-PP) ultrathin film by means of the LBL strategy, giving rise to an excellent OER performance [142]. Compared with other interlayer anions, like sodium polystyrenesulfonate (PSS) and sodium dodecyl sulfate (SDS), CoNi-LDH NS assembled with Fe-PP shows superior OER activity, which may benefit from the excellent conductivity of Fe-PP. Moreover, LDHs with various host composition has also been combined with Fe-PP, such as CoMn-, CoFe-, and ZnCo-LDH, to form LDH NS/Fe-PP ultrathin films (UTFs). As a result, the OER performance of all these LDH NS/Fe-PP UTFs is significantly improved (Figure 8a), which means the conductive interlayer anions, like Fe-PP can efficiently improve the OER catalytic activities of LDHs. In addition, the increased intersheet spacing would be expected to facilitate $\mathrm{OH}^{-} / \mathrm{O}_{2}$ transport through the film. Xu et al. synthesized NiFe-LDH by introducing $\mathrm{CO}_{3}{ }^{2-}$ to replace $\mathrm{NO}_{3}{ }^{-}$, leading to the reducing of interlayer spacing and poor OER catalytic activity [71]. On the basis of $\mathrm{OH}^{-}$being the main reactant in alkaline solution, the $\mathrm{NO}_{3}{ }^{-}$has a better exchange ability with $\mathrm{OH}^{-}$in interlamination, which also affects the OER performance of NiFe-LDH. Hunter et al. synthesized NiFe-LDH with 12 different interlayer anions, which shows different activities during OER reactions [143]. As shown in Figure 8b, overpotentials of [NiFe]-LDH materials with different interlayer anions illustrate that the measured overpotentials, which reflects the water oxidation abilities, do not match with the basal spacing. Further study shows that strong correlation can be found between the $\mathrm{pKa}$ values of the interlayer anoins and overpotentials. As shown in Figure $8 \mathrm{c}$, there is a midpoint of $3.4 \pm 0.7$. Considering the existence of $1 \mathrm{M} \mathrm{OH}^{-}$in the electrolyte, it is clear that the di- and trivalent anions outcompeted the hydroxide that presented in the interlayer. This means that di- and trivalent anions can be seen as strongly-bound proton acceptors which can reduce the activation barrier for water oxidation. Interestingly, the DFT calculations suggest that the XPS signal at $405.1 \mathrm{eV}$ correspond to the nitrite bound by its $\mathrm{N}$-atom to edge-site iron, which is a symbol of high water oxidation activity (Figure 8d). In addition, the oxidation of NiFe-LDH in the alkaline media will generate the $\mathrm{NiFeOOH}$ along with the detachment of $\mathrm{H}$ from the topmost surface of the regular LDH. Zhang et al. found that the presence of interlayer $\mathrm{CO}_{3}{ }^{2-}$ anions stabilized the active sites of LDHs [144]. As discussed above, the distance of interlayer space, as well as the chemical environment induced by the interlayer anions, play an important role in the OER activity of LDHs. Additionally, iron sites at the edges of [NiFe]-LDH nanosheets may be active in water oxidation catalysis through the related studies [145]. We expect that these findings can be potentially used in the engineering of OER catalysts. 

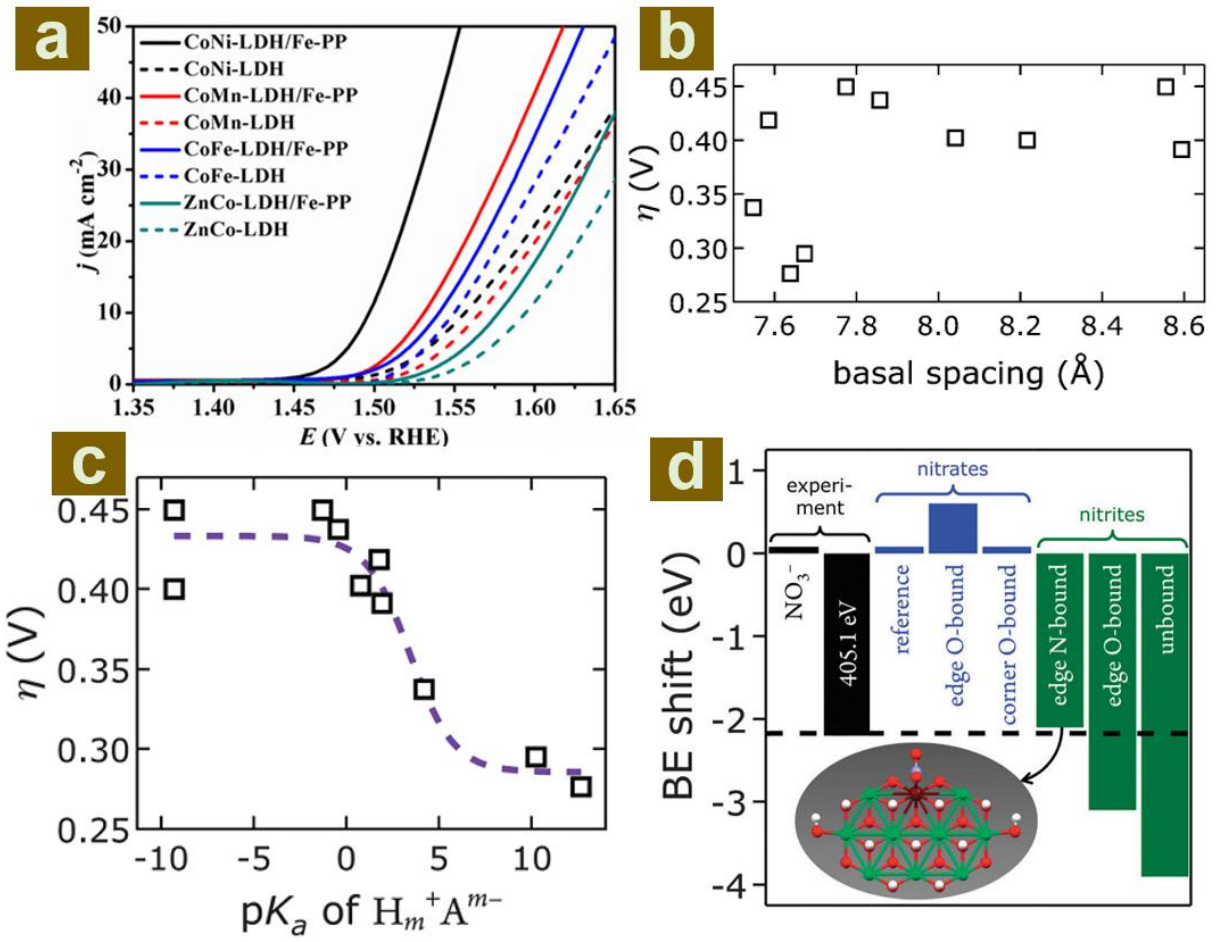

Figure 8. (a) LSV curves for various LDHs assembled with Fe-PP. Reproduced from [142], Copyright Royal of Society, 2016. (b) Observed overpotentials $\eta$ as a function of the basal spacing of NiFe-LDH materials with different interlayer anions. (c) Overpotentials $\eta$ of NiFe-LDH materials with different interlayer anions $\mathrm{A}^{\mathrm{m}-}$. (d) Measured (black) and calculated X-ray photoelectron spectroscopy (XPS) binding energy (BE) core level shifts (is-CLS) for differently-bound nitrates (blue) and nitrites (green) with a calculated structure that is consistent with the feature at $405.1 \mathrm{eV}$. Atom colors: Ni, green; Fe, maroon; N, blue; O, red; H, white. Reproduced from [143], Copyright Royal of Society, 2016.

\section{Conclusions and Perspectives}

In summary, we have systematically introduced the recent progress about LDHs, themselves, for electrochemical water oxidation from the view of host and guest engineering. The potential active sites of LDH have been scientifically discussed based on previous experiments and calculation. The metal ion ratio in the LDHs' host layer obviously affects their OER activity. The determination of the valence state of metal ions during water oxidation has been widely used to investigate the active sites of $\mathrm{LDH}$, while this probably depends on the metal and water oxidation rate. As for guest anions, changing the space of the interlayer and the chemical properties (such as acidity and alkalinity) provides a chance to optimize of electrochemical performances for LDHs. Since the nanostructures have a profound impact on electrode materials, it is significant to synthesize uniform and highly-dispersed LDHs with all the active sites exposed to the electrolyte, such as ultrathin nanosheet arrays.

In the future, molecular-level control remains promising to entirely develop the potential of LDH-based OER electrocatalysts. Host-guest interaction of LDHs provides a large space for turning their electrochemical properties for molecule adsorption and catalytic transformation. Additionally, the defect chemistry of LDHs have also been paid increased attention, owing to the significantly-improved surface electronic structures. This also extends the question as to whether the surface or sites show a higher activity for the OER process because of their different defects. Despite the importance of optimizing the material properties, it is still a long way to the synthesis of low-cost and high-quality LDH-based electrocatalysts with precise control over their composition, structure, and morphology. To utilize solar energy in water splitting, how to combine the novel 
LDH-based OER catalysts with photocatalysts will be a promising method to achieve an efficient photoelectrochemical process.

Acknowledgments: This work was supported by the National Natural Science Foundation of China, the 973 Program (grant no. 2014CB932102), the Fundamental Research Funds for the Central Universities (buctylkxj01; PYCC1704) and the R and D department of PetroChina.

Conflicts of Interest: The authors declare no conflict of interest.

\section{References}

1. Menezes, P.W.; Indra, A.; Das, C.; Walter, C.; Göbel, C.; Vitaly, G.V.; Schmeißer, D.; Driess, M. Uncovering the nature of active species of nickel phosphide catalysts in high-performance electrochemical overall water splitting. ACS Catal. 2017, 7, 103-109. [CrossRef]

2. Hou, Y.; Qiu, M.; Zhang, T.; Ma, J.; Liu, S.H.; Zhuang, X.D.; Yuan, C.; Feng, X.L. Efficient electrochemical and photoelectrochemical water splitting by a 3D nanostructured carbon supported on flexible exfoliated graphene foil. Adv. Mater. 2017, 29, 1604480.

3. Ryu, S.J.; Hoffmann, M.R. Mixed-metal semiconductor anodes for electrochemical water splitting and reactive chlorine species generation: Implications for electrochemical wastewater treatment. Catalysts 2016, 6, 59. [CrossRef]

4. Li, X.M.; Hao, X.G.; Abudula, A.; Guan, G.Q. Nanostructured catalysts for electrochemical water splitting: Current state and prospects. J. Mater. Chem. A 2016, 4, 11973-12000.

5. Reier, T.; Pawolek, Z.; Cherevko, S.; Bruns, M.; Jones, T.; Teschner, D.; Selve, S.; Bergmann, A.; Nong, H.N.; Schlögl, R.; et al. Molecular insight in structure and activity of highly efficient, low-Ir Ir-Ni oxide catalysts for electrochemical water splitting. J. Am. Chem. Soc. 2015, 137, 13031-13040. [CrossRef] [PubMed]

6. Liu, S.Y.; Li, L.J.; Ahn, H.S.; Manthiram, A. Delineating the roles of $\mathrm{Co}_{3} \mathrm{O}_{4}$ and $\mathrm{N}$-doped carbon nanoweb (CNW) in bifunctional $\mathrm{Co}_{3} \mathrm{O}_{4} / \mathrm{CNW}$ catalysts for oxygen reduction and oxygen evolution reactions. J. Mater. Chem. A 2015, 3, 11615-11623. [CrossRef]

7. Li, P.X.; Ma, R.G.; Zhou, Y.; Chen, Y.F.; Zhou, Z.Z.; Liu, G.H.; Liu, Q.; Peng, G.H.; Liang, Z.H.; Wang, J.C. In situ growth of spinel $\mathrm{CoFe}_{2} \mathrm{O}_{4}$ nanoparticles on rod-like ordered mesoporous carbon for bifunctional electrocatalysis of both oxygen reduction and oxygen evolution. J. Mater. Chem. A 2015, 3, 15598-15606. [CrossRef]

8. Hutchings, G.S.; Zhang, Y.; Li, J.; Yonemoto, B.Y.; Zhou, X.G.; Zhu, K.K.; Jiao, F. In situ formation of cobalt oxide nanocubanes as efficient oxygen evolution catalysts. J. Am. Chem. Soc. 2015, 137, 4223-4229. [CrossRef] [PubMed]

9. Wu, L.H.; Li, Q.; Wu, C.H.; Zhu, H.Y.; Garcia, A.M.; Shen, B.; Guo, J.H.; Sun, S.H. Stable cobalt nanoparticles and their monolayer array as an efficient electrocatalyst for oxygen evolution reaction. J. Am. Chem. Soc. 2015, 137, 7071-7074. [CrossRef] [PubMed]

10. He, G.W.; Zhang, W.; Deng, Y.D.; Zhong, C.; Hu, W.B.; Han, X.P. Engineering pyrite-type bimetallic Ni-doped $\mathrm{CoS}_{2}$ nanoneedle arrays over a wide compositional range for enhanced oxygen and hydrogen electrocatalysis with flexible property. Catalysts 2017, 7, 366. [CrossRef]

11. Cherevko, S.; Geiger, S.; Kasian, O.; Kulyk, O.; Grote, J.P.; Savan, A.; Shrestha, B.R.; Merzlikin, S.; Breitbach, B.; Ludwig, A.; et al. Oxygen and hydrogen evolution reactions on $\mathrm{Ru}, \mathrm{RuO}_{2}$, $\mathrm{Ir}$, and $\mathrm{IrO}_{2}$ thin film electrodes in acidic and alkaline electrolytes: A comparative study on activity and stability. Catalysis Today 2016, 262, 170-180. [CrossRef]

12. Lee, Y.M.; Suntivich, J.; May, K.J.; Perry, E.E.; Yang, S.H. Synthesis and activities of rutile $\mathrm{IrO}_{2}$ and $\mathrm{RuO}_{2}$ nanoparticles for oxygen evolution in acid and alkaline solutions. J. Phys. Chem. Lett. 2012, 3, 399-404. [CrossRef] [PubMed]

13. Bates, M.K.; Jia, Q.Y.; Doan, H.; Liang, W.T.; Mukerjee, S. Charge-transfer effects in Ni-Fe and Ni-Fe-Co. mixed-metal oxides for the alkaline oxygen evolution reaction. ACS Catal. 2016, 6, 155-161. [CrossRef]

14. Weng, B.C.; $\mathrm{Xu}$, F.H.; Wang, C.L.; Meng, W.W.; Grice, C.R.; Yan, Y.F. A layered $\mathrm{Na}_{1-\mathrm{x}} \mathrm{Ni}_{\mathrm{y}} \mathrm{Fe}_{1-\mathrm{y}} \mathrm{O}_{2}$ double oxide oxygen evolution reaction electrocatalyst for highly efficient water-splitting. Energy Environ. Sci. 2017, 10, 121-128. [CrossRef] 
15. Han, X.L.; Yu, Y.F.; Huang, Y.; Liu, D.L.; Zhang, B. Photogenerated carriers boost water splitting activity over transition-metal/semiconducting metal oxide bifunctional electrocatalysts. ACS Catal. 2017, 7, 6464-6470. [CrossRef]

16. Lu, F.; Zhou, M.; Zhou, Y.X.; Zeng, X.H. First-row transition metal based catalysts for the oxygen evolution reaction under alkaline conditions: Basic principles and recent advances. Small 2017, 13, 1701931. [CrossRef] [PubMed]

17. Stevens, M.B.; Enman, L.J.; Batchellor, A.S.; Cosby, M.R.; Vise, A.E.; Trang, C.D.M.; Boettcher, S.W. Measurement techniques for the study of thin film heterogeneous water oxidation electrocatalysts. Chem. Mater. 2017, 29, 120-140. [CrossRef]

18. Han, L.; Dong, S.J.; Wang, E.K. Transition-metal (CO, Ni, and Fe)-based electrocatalysts for the water oxidation reaction. Adv. Mater. 2016, 28, 9266-9291. [CrossRef] [PubMed]

19. Tan, C.L.; Cao, X.H.; Wu, X.J.; He, Q.Y.; Yang, J.; Zhang, X.; Chen, J.Z.; Zhao, W.; Han, S.K.; Nam, G.H.; et al. Recent advances in ultrathin two-dimensional nanomaterials. Chem. Rev. 2017, 117, 6225-6331. [CrossRef] [PubMed]

20. Zhu, X.L.; Tang, C.; Wang, H.F.; Zhang, Q.; Yang, C.H.; Wei, F. Dual-sized NiFe layered double hydroxides in situ grown on oxygen-decorated self-dispersal nanocarbon as enhanced water oxidation catalysts. J. Mater. Chem. A 2015, 3, 24540-24546. [CrossRef]

21. Zhou, L.; Shao, M.F.; Li, J.B.; Jiang, S.; Wei, M.; Duan, X. Two-dimensional ultrathin arrays of CoP: Electronic modulation toward high performance overall water splitting. Nano Energy 2017, 41, 583-590. [CrossRef]

22. Zhang, G.; Wang, G.C.; Liu, Y.; Liu, H.J.; Qu, J.H.; Li, J.H. Highly active and stable catalysts of phytic acid-derivative transition metal phosphides for full water splitting. J. Am. Chem. Soc. 2016, 138, 14686-14693. [CrossRef] [PubMed]

23. Tan, Y.W.; Wang, H.; Liu, P.; Shen, Y.H.; Cheng, C.; Hirata, A.; Fujita, T.; Tang, Z.; Chen, M.W. Versatile nanoporous bimetallic phosphides towards electrochemical water splitting. Energy Environ. Sci. 2016, 9, 2257-2261. [CrossRef]

24. Li, W.; Zhang, S.L.; Fan, Q.N.; Zhang, F.Z.; Xu, S.L. Hierarchically scaffolded CoP/CoP 2 nanoparticles: Controllable synthesis and their application as a well-matched bifunctional electrocatalyst for overall water splitting. Nanoscale 2017, 9, 5677-5685. [CrossRef] [PubMed]

25. Corrigan, D.A. The catalysis of the oxygen evolution reaction by iron impurities in thin film nickel oxide electrodes. J. Electrochem. Soc. 1987, 134, 377-384. [CrossRef]

26. Gong, M.; Li, Y.G.; Wang, H.L.; Liang, Y.Y.; Wu, J.Z.; Zhou, J.G.; Wang, J.; Regier, T.; Wei, F.; Dai, H.J. An advanced Ni-Fe layered double hydroxide electrocatalyst for water oxidation. J. Am. Chem. Soc. 2013, 135, 8452-8455. [CrossRef] [PubMed]

27. Shao, M.F.; Ning, F.Y.; Zhao, J.W.; Wei, M.; Evans, D.G.; Duan, X. Preparation of $\mathrm{Fe}_{3} \mathrm{O}_{4} @ \mathrm{SiO}_{2} @ l$ layered double hydroxide core-shell microspheres for magnetic separation of proteins. J. Am. Chem. Soc. 2012, 134, 1071-1077. [CrossRef] [PubMed]

28. Evans, D.G.; Duan, X. Preparation of layered double hydroxides and their applications as additives in polymers, as precursors to magnetic materials and in biology and medicine. Chem. Commun. 2006, 0, 485-496. [CrossRef] [PubMed]

29. Wang, Q.; O'Hare, D. Recent advances in the synthesis and application of layered double hydroxide (LDH) nanosheets. Chem. Rev. 2012, 7, 4124-4155. [CrossRef] [PubMed]

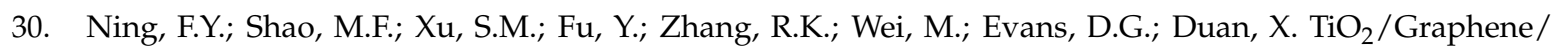
NiFe-layered double hydroxide nanorod array photoanodes for efficient photoelectrochemical water splitting. Energy Environ. Sci. 2016, 9, 2633-2643. [CrossRef]

31. Zhang, H.J.; Li, X.P.; Hahnel, A.; Naumann, V.; Lin, C.; Azimi, S.; Schweizer, S.L.; Maijenburg, A.W.; Wehrspohn, R.B. Bifunctional heterostructure assembly of NiFe LDH nanosheets on NiCoP nanowires for highly efficient and stable overall water splitting. Adv. Funct. Mater. 2018, 28, 1706847. [CrossRef]

32. Lu, Z.Y.; Xu, W.W.; Zhu, W.; Yang, Q.; Lei, X.D.; Liu, J.F.; Li, Y.P.; Sun, X.M.; Duan, X. Three-dimensional $\mathrm{NiFe}$ layered double hydroxide film for high- efficiency oxygen evolution reaction. Chem. Commun. 2014, 50, 6479-6482. [CrossRef] [PubMed]

33. Hou, Y.; Lohe, M.R.; Zhang, J.; Liu, S.H.; Zhuang, X.D.; Feng, X.L. Vertically oriented cobalt selenide/NiFe layered-double-hydroxide nanosheets supported on exfoliated graphene foil: An efficient 3D electrode for overall water splitting. Energy Environ. Sci. 2016, 9, 478-483. [CrossRef] 
34. Wang, Q.; Shang, L.; Shi, R.; Zhang, X.; Zhao, Y.F.; Waterhouse, G.I.N.; Wu, L.Z.; Tung, C.H.; Zhang, T.Z. $\mathrm{NiFe}$ layered double hydroxide nanoparticles on Co., N-codoped carbon nanoframes as efficient bifunctional catalysts for rechargeable zinc-air batteries. Adv. Energy Mater. 2017, 7, 1700467. [CrossRef]

35. Li, Y.G.; Gong, M.; Liang, Y.Y.; Feng, J.; Kim, J.E.; Wang, H.L.; Hong, G.S.; Zhang, B.; Dai, H.J. Advanced zinc-air batteries based on high-performance hybrid electrocatalysts. Nat. Commun. 2013, 4, 1805. [CrossRef] [PubMed]

36. Tang, D.; Liu, J.; Wu, X.Y.; Liu, R.H.; Han, X.; Han, Y.Z.; Huang, H.; Liu, Y.; Kang, Z.H. Carbon quantum dot/NiFe layered double-hydroxide composite as a highly efficient electrocatalyst for water oxidation. ACS Appl. Mater. Interfaces 2014, 6, 7918-7925. [CrossRef] [PubMed]

37. Ma, W.; Ma, R.Z.; Wang, C.X.; Liang, J.B.; Liu, X.H.; Zhou, K.C.; Sasaki, T. A superlattice of alternately stacked $\mathrm{Ni}-\mathrm{Fe}$ hydroxide nanosheets and graphene for efficient splitting of water. ACS Nano 2015, 9, 1977-1984. [CrossRef] [PubMed]

38. Tang, C.; Wang, H.S.; Wang, H.F.; Zhang, Q.; Tian, G.L.; Nie, J.Q.; Wei, F. Spatially confined hybridization of nanometer-sized NiFe hydroxides into nitrogen-doped graphene frameworks leading to superior oxygen evolution reactivity. Adv. Mater. 2015, 27, 4516-4522. [CrossRef] [PubMed]

39. Tang, D.; Han, Y.Z.; Ji, W.B.; Qiao, S.; Zhou, X.; Liu, R.H.; Han, X.; Huang, H.; Liu, Y.; Kang, Z.H. A high-performance reduced grapheme oxide/ZnCo layered double hydroxide electrocatalyst for efficient water oxidation. Dalton Trans. 2014, 43, 15119-15125. [CrossRef] [PubMed]

40. Long, X.; Li, J.K.; Xiao, S.; Yan, K.Y.; Wang, Z.L.; Chen, H.N.; Yang, S.H. A strongly coupled graphene and FeNi double hydroxide hybrid as an excellent electrocatalyst for the oxygen evolution reaction. Angew. Chem. Int. Ed. 2014, 53, 7584-7588. [CrossRef] [PubMed]

41. Ma, W.; Ma, R.Z.; Wu, J.H.; Sun, P.Z.; Liu, X.H.; Zhou, K.C.; Sasaki, T. Development of efficient electrocatalysts via molecular hybridization of NiMn layered double hydroxide nanosheets and grapheme. Nanoscale 2016, 8, 10425-10432. [CrossRef] [PubMed]

42. Vargas, G.; Vazquez, S.J.; Oliver, T.M.A.; Ramos, S.L.; Flores, M.G.; Reguera, E. Influence on the electrocatalytic water oxidation of $\mathrm{M}^{2+} / \mathrm{M}^{3+}$ cation arrangement in $\mathrm{NiFe} \mathrm{LDH}$ : Experimental and theoretical DFT evidences. Electrocatalysis 2017, 8, 383-391. [CrossRef]

43. Han, N.; Zhao, F.P.; Li, Y.G. Ultrathin nickel-iron layered double hydroxide nanosheets intercalated with molybdate anions for electrocatalytic water oxidation. J. Mater. Chem. A 2015, 3, 16348-16353. [CrossRef]

44. Gao, R.; Yan, D.P. Fast formation of single-unit-cell-thick and defect-rich layered double hydroxide nanosheets with highly enhanced oxygen evolution reaction for water splitting. Nano Res. 2018, 11, 1883-1894. [CrossRef]

45. Luo, M.; Cai, Z.; Wang, C.; Bi, Y.M.; Qian, L.; Hao, Y.C.; Li, L.; Kuang, Y.; Li, Y.P.; Lei, X.D.; et al. Phosphorus oxoanion-intercalated layered double hydroxides for high-performance oxygen evolution. Nano Res. 2017, 10, 1732-1739. [CrossRef]

46. Ge, X.; Gu, C.D.; Wang, X.L.; Tu, J.P. Ionothermal synthesis of cobalt iron layered double hydroxides (LDHs) with expanded interlayer spacing as advanced electrochemical materials. J. Mater. Chem. A 2014, 2, 17066-17076. [CrossRef]

47. Jin, H.Y.; Mao, S.J.; Zhan, G.P.; Xu, F.; Bao, X.B.; Wang, Y. Fe incorporated $\alpha-\mathrm{Co}(\mathrm{OH})_{2}$ nanosheet with remarkably improved activity towards oxygen evolution reaction. J. Mater. Chem. A 2017, 5, 1078-1084. [CrossRef]

48. Wang, D.Y.; Costa, F.R.; Vyalikh, A.; Leuteritz, A.; Scheler, U.; Jehnichen, D.; Wagenknech, U.; Häussler, L.; Heinrich, G. One-step synthesis of organic LDH and its comparison with regeneration and anion exchange method. Chem. Mater. 2009, 21, 4490-4497. [CrossRef]

49. Xu, H.J.; Wang, B.K.; Shan, C.F.; Xi, P.X.; Liu, W.S.; Tang, Y. Ce-doped NiFe-layered double hydroxide ultrathin nanosheets/nanocarbon hierarchical nanocomposite as an efficient oxygen evolution catalyst. ACS Appl. Mater. Interfaces 2018, 10, 6336-6345. [CrossRef] [PubMed]

50. Trotochaud, L.; Young, S.L.; Ranney, J.K.; Boettcher, S.W. Nickel-iron oxyhydroxide oxygen-evolution electrocatalysts: The role of intentional and incidental iron incorporation. J. Am. Chem. Soc. 2014, 136, 6744-6753. [CrossRef] [PubMed]

51. Chen, J.Y.C.; Dang, L.; Liang, H.F.; Bi, W.L.; Gerken, J.B.; Jin, S.; Alp, E.E.; Stahl, S.S. Operando analysis of $\mathrm{NiFe}$ and Fe oxyhydroxide electrocatalysts for water oxidation: Detection of $\mathrm{Fe}^{4+}$ by Mössbauer spectroscopy. J. Am. Chem. Soc. 2015, 137, 15090-15093. [CrossRef] [PubMed] 
52. Gong, M.; Dai, H.J. A mini review of NiFe-based materials as highly active oxygen evolution reaction electrocatalysts. Nano Res. 2015, 8, 23-39. [CrossRef]

53. Shao, M.F.; Zhang, R.K.; Li, Z.H.; Wei, M.; Evans, D.G.; Duan, X. Layered double hydroxides toward electrochemical energy storage and conversion: Design, synthesis and applications. Chem. Commun. 2015, 51, 15880-15893. [CrossRef] [PubMed]

54. Dionigi, F.; Strasser, P. NiFe-based (oxy)hydroxide catalysts for oxygen evolution reaction in non-acidic electrolytes. Adv. Energy Mater. 2016, 6, 1600621. [CrossRef]

55. Burke, M.S.; Enman, L.J.; Batchellor, A.S.; Zou, S.H.; Boettcher, S.W. Oxygen evolution reaction electrocatalysis on transition metal oxides and (oxy)hydroxides: Activity trends and design principles. Chem. Mater. 2015, 27, 7549-7558. [CrossRef]

56. Tang, C.; Titirici, M.M.; Zhang, Q. A review of nanocarbons in energy electrocatalysis: Multifunctional substrates and highly active sites. J. Energy Chem. 2017, 26, 1077-1093. [CrossRef]

57. Suen, N.T.; Hung, S.F.; Quan, Q.; Zhang, N.; Xu, Y.J.; Chen, H.M. Electrocatalysis for the oxygen evolution reaction: recent development and future perspectives. Chem. Soc. Rev. 2017, 46, 337-365. [CrossRef] [PubMed]

58. Li, Y.B.; Zhao, C. Iron-doped nickel phosphate as synergistic electrocatalyst for water oxidation. Chem. Mater. 2016, 28, 5659-5666. [CrossRef]

59. Xi, W.; Ren, Z.Y.; Kong, L.J.; Wu, J.; Du, S.C.; Zhu, J.Q.; Xue, Y.Z.; Meng, H.Y.; Fu, H.G. Dual-valence nickel nanosheets covered with thin carbon as bifunctional electrocatalysts for full water splitting. J. Mater. Chem. A 2016, 4, 7297-7304. [CrossRef]

60. Pfrommer, J.; Azarpira, A.; Steigert, A.; Olech, K.; Menezes, P.W.; Duarte, R.F.; Liao, X.X.; Wilks, R.G.; Bär, M.; Thomas, S.N.; et al. Active and stable nickel-based electrocatalysts based on the ZnO:Ni system for water oxidation in alkaline media. ChemCatChem 2017, 9, 672-676. [CrossRef]

61. Luo, P.; Zhang, H.J.; Liu, L.; Zhang, Y.; Deng, J.; Xu, C.H.; Hu, N.; Wang, Y. Targeted synthesis of unique nickel sulfide (NiS, $\mathrm{NiS}_{2}$ ) microarchitectures and the applications for the enhanced water splitting system. ACS Appl. Mater. Interfaces 2017, 9, 2500-2508. [CrossRef] [PubMed]

62. Friebel, D.; Louie, M.W.; Bajdich, M.; Sanwald, K.E.; Cai, Y.; Wise, A.M.; Cheng, M.J.; Sokaras, D.; Weng, T.C.; Mori, R.A.; et al. Identification of highly active Fe sites in (Ni,Fe)OOH for electrocatalytic water splitting. J. Am. Chem. Soc. 2015, 137, 1305-1313. [CrossRef] [PubMed]

63. Tang, C.; Wang, H.F.; Wang, H.S.; Wei, F.; Zhang, Q. Guest-host modulation of multi-metallic (oxy)hydroxides for superb water oxidation. J. Mater. Chem. A 2016, 4, 3210-3216. [CrossRef]

64. Gorlin, M.; Chernev, P.; Araujo, J.F.; Reier, T.; Dresp, S.; Paul, B.; Krahnert, R.; Dau, H.; Strasser, P. Oxygen evolution reaction dynamics, faradaic charge efficiency, and the active metal redox states of $\mathrm{Ni}$-Fe oxide water splitting electrocatalysts. J. Am. Chem. Soc. 2016, 138, 5603-5614. [CrossRef] [PubMed]

65. Liu, H.J.; Zhou, J.; Wu, C.Q.; Wang, C.D.; Zhang, Y.K.; Liu, D.B.; Lin, Y.X.; Jiang, H.L.; Song, L. Integrated flexible electrode for oxygen evolution reaction: layered double hydroxide coupled with single-walled carbon nanotubes film. ACS Sustainable Chem. Eng. 2018, 6, 2911-2915. [CrossRef]

66. Yang, Y.; Dang, L.; Shearer, M.J.; Sheng, H.Y.; Li, W.J.; Chen, J.; Xiao, P.; Zhang, Y.H.; Hamers, R.J.; Jin, S. Highly active trimetallic $\mathrm{NiFeCr}$ layered double hydroxide electrocatalysts for oxygen evolution reaction. Adv. Energy Mater. 2018, 1703189. [CrossRef]

67. Sun, X.H.; Shao, Q.; Pi, Y.C.; Guo, J.; Huang, X.Q. A general approach to synthesise ultrathin NiM(M=Fe, Co, $\mathrm{Mn}$ ) hydroxide nanosheets as high performance low-cost electrocatalysts for overall water splitting. J. Mater. Chem. A 2017, 5, 7769-7775. [CrossRef]

68. Li, Z.H.; Shao, M.F.; An, H.L.; Wang, Z.X.; Xu, S.M.; Wei, M.; Evans, D.G.; Duan, X. Fast electrosynthesis of Fe-containing layered double hydroxide arrays toward highly efficient electrocatalytic oxidation reactions. Chem. Sci. 2015, 6, 6624-6631. [CrossRef] [PubMed]

69. Li, X.M.; Hao, X.G.; Wang, Z.D.; Abudula, A.; Guan, G.Q. In-situ intercalation of NiFe LDH materials: An efficient approach to improve electrocatalytic activity and stability for water splitting. J. Power Sources 2017, 347, 193-200. [CrossRef]

70. Yang, H.D.; Luo, S.; Bao, Y.; Luo, Y.T.; Jin, J.; Ma, J.T. In situ growth of ultrathin Ni-Fe LDH nanosheets for high performance oxygen evolution reaction. Inorg. Chem. Front. 2017, 4, 1173-1181. [CrossRef] 
71. Xu, Y.Q.; Hao, Y.C.; Zhang, G.X.; Lu, Z.Y.; Han, S.; Li, Y.P.; Sun, X.M. Room-temperature synthetic NiFe layered double hydroxide with different anions intercalation as an excellent oxygen evolution catalyst. RSC Adv. 2015, 5, 55131-55135. [CrossRef]

72. Zhang, Y.; Shao, Q.; Pi, Y.C.; Guo, J.; Huang, X.Q. A cost-effiient bifunctional ultrathin nanosheets array for electrochemical overall water splitting. Small 2017, 13, 1700355. [CrossRef] [PubMed]

73. Tian, X.Q.; Liu, Y.H.; Xiao, D.; Sun, J. Ultrafast and large scale preparation of superior catalyst for oxygen evolution reaction. J. Power Sources 2017, 365, 320-326. [CrossRef]

74. Zhou, T.T.; Cao, Z.; Wang, H.; Gao, Z.; Lia, L.; Mab, H.Y.; Zhao, Y.F. Ultrathin Co-Fe hydroxide nanosheet arrays for improved oxygen evolution during water splitting. RSC Adv. 2017, 7, 22818-22824. [CrossRef]

75. Feng, L.X.; Li, A.R.; Li, Y.X.; Liu, J.; Wang, L.D.Y.; Huang, L.Y.; Wang, Y.; Ge, X.B. A highly active CoFe layered double hydroxide for water splitting. ChemPlusChem 2017, 82, 483-488. [CrossRef]

76. Zhou, P.; Wang, Y.Y.; Xie, C.; Chen, C.; Liu, H.W.; Chen, R.; Huo, J.; Wang, S.Y. Acid-etched layered double hydroxides with rich defects for enhancing the oxygen evolution reaction. Chem. Commun. 2017, 53, 11778-11781. [CrossRef] [PubMed]

77. Liu, P.F.; Yang, S.; Zhang, B.; Yang, H.G. Defect-rich ultrathin cobalt-iron layered double hydroxide for electrochemical overall water splitting. ACS Appl. Mater. Interfaces 2016, 8, 34474-34481. [CrossRef] [PubMed]

78. Wang, Y.Y.; Zhang, Y.Q.; Liu, Z.J.; Xie, C.; Feng, S.; Liu, D.D.; Shao, M.F.; Wang, S.Y. Layered double hydroxide nanosheets with multiple vacancies obtained by dry exfoliation as highly efficient oxygen evolution electrocatalysts. Angew. Chem. Int. Ed. 2017, 56, 5867-5871. [CrossRef] [PubMed]

79. Sumboja, A.; Chen, J.W.; Zong, Y.; Lee, P.S.; Liu, Z.L. NiMn layered double hydroxide as efficient electrocatalyst for oxygen evolution reaction and its application in rechargeable $\mathrm{Zn}$ air batteries. Nanoscale 2017, 9, 774-780. [CrossRef] [PubMed]

80. Song, F.; Hu, X.L. Ultrathin cobalt-manganese layered double hydroxide is an efficient oxygen evolution catalyst. J. Am. Chem. Soc. 2014, 136, 16481-16484. [CrossRef] [PubMed]

81. Jiang, J.; Zhang, A.L.; Li, L.L.; Ai, L.H. Nickel-cobalt layered double hydroxide nanosheets as high performance electrocatalyst for oxygen evolution reaction. J. Power Sources 2015, 278, 445-451. [CrossRef]

82. Liu, W.J.; Bao, J.; Guan, M.L.; Zhao, Y.; Lian, J.B.; Qiu, J.X.; Xu, L.; Huang, Y.P.; Qian, J.; Li, H.M. Nickel-cobalt-layered double hydroxide nanosheet arrays on $\mathrm{Ni}$ foam as a bifunctional electrocatalyst for overall water splitting. Dalton Trans. 2017, 46, 8372-8376. [CrossRef] [PubMed]

83. Liang, H.F.; Meng, F.; Acevedo, M.C.; Li, L.C.; Forticaux, A.; Xiu, L.C.; Wang, Z.C.; Ji, S. Hydrothermal continuous flow synthesis and exfoliation of NiCo layered double hydroxide nanosheets for enhanced oxygen evolution catalysis. Nano Lett. 2015, 15, 1421-1427. [CrossRef] [PubMed]

84. Qiao, C.; Zhang, Y.; Zhu, Y.Q.; Cao, C.B.; Bao, X.H.; Xu, J.Q. One-step synthesis of zinc-cobalt layered double hydroxide ( $\mathrm{Zn}-\mathrm{Co}-\mathrm{LDH})$ nanosheets for high efficiency oxygen evolution reaction. J. Mater. Chem. A 2015, 3, 6878-6883. [CrossRef]

85. Dong, C.L.; Yuan, X.T.; Wang, X.; Liu, X.Y.; Dong, W.J.; Wang, R.Q.; Duan, Y.H.; Huang, F.Q. Rational design of cobalt-chromium layered double hydroxide as a highly efficient electrocatalyst for water oxidation. J. Mater. Chem. A 2016, 4, 11292-11298. [CrossRef]

86. Yang, F.K.; Sliozberg, K.R.; Sinev, I.; Antoni, H.; Bähr, A.; Ollegott, K.; Xia, W.; Mas, J.; Grünert, W.; Cuenya, B.R.; et al. Synergistic effect of cobalt and iron in layered double hydroxide catalysts for the oxygen evolution reaction. ChemSusChem 2017, 10, 156-165. [CrossRef] [PubMed]

87. Lu, Z.Y.; Qian, L.; Tian, Y.; Li, Y.P.; Sun, X.M.; Duan, X. Ternary NiFeMn layered double hydroxides as highly-efficient oxygen evolution catalysts. Chem. Commun. 2016, 52, 90-911. [CrossRef] [PubMed]

88. Fan, K.; Chen, H.; Ji, Y.F.; Huang, H.; Claesson, P.M.; Daniel, Q.; Bertrand Philippe, B.; Rensmo, H.; Li, F.S.; Luo, Y.; et al. Nickel-vanadium monolayer double hydroxide for efficient electrochemical water oxidation. Nat. Commun. 2016, 7, 11981. [CrossRef] [PubMed]

89. Yoon, S.H.; Yun, J.Y.; Lim, J.H.; Yoo, B.Y. Enhanced electrocatalytic properties of electrodeposited amorphous cobalt-nickel hydroxide nanosheets on nickel foam by the formation of nickel nanocones for the oxygen evolution reaction. J. Alloys Compd. 2017, 693, 964-969. [CrossRef]

90. Long, X.; Xiao, S.; Wang, Z.L.; Zheng, X.L.; Yang, S.H. Co intake mediated formation of ultrathin nanosheets of transition metal LDH—an advanced electrocatalyst for oxygen evolution reaction. Chem. Commun. 2015, 51, 1120-1123. [CrossRef] [PubMed] 
91. Song, F.; Hu, X.L. Exfoliation of layered double hydroxides for enhanced oxygen evolution catalysis. Nat. Commun. 2014, 5, 4477. [CrossRef] [PubMed]

92. Yan, D.F.; Li, Y.X.; Huo, J.; Chen, R.; Dai, L.M.; Wang, S.Y. Defect chemistry of nonprecious-metal electrocatalysts for oxygen reactions. Adv. Mater. 2017, 29, 1606459. [CrossRef] [PubMed]

93. Dogan, F.; Long, B.R.; Croy, J.R.; Gallagher, K.G.; Iddir, H.; Russell, J.T.; Balasubramanian, M.; Key, B. Re-entrant lithium local environments and defect driven electrochemistry of Li- and Mn-rich Li-ion battery cathodes. J. Am. Chem. Soc. 2015, 6, 2328-2335. [CrossRef] [PubMed]

94. Gu, Y.Q.; Xu, K.; Wu, C.Z.; Zhao, J.Y.; Xie, Y. Surface chemical-modification for engineering the intrinsic physical properties of inorganic two-dimensional nanomaterials. Chem. Soc. Rev. 2015, 44, 637-646. [CrossRef] [PubMed]

95. Hartmann, P.; Brezesinski, T.; Sann, J.; Lotnyk, A.; Eufinger, J.P.; Kienle, L.; Janek, J. Defect chemistry of oxide nanomaterials with high surface area: Ordered mesoporous thin films of the oxygen storage catalyst $\mathrm{CeO}_{2}-\mathrm{ZrO}_{2}$. ACS Nano 2013, 7, 2999-3013. [CrossRef] [PubMed]

96. Dou, L.; Wong, A.B.; Yu, Y.; Lai, M.L.; Kornienko, N.; Eaton, S.W.; Fu, A.; Bischak, C.G.; Ma, J.; Ding, T.; et al. Atomically thin two-dimensional organic-inorganic hybrid perovskites. Science 2015, 349, 1518-1521. [CrossRef] [PubMed]

97. Smith, R.J.; King, P.J.; Lotya, M.; Wirtz, C.; Khan, U.; De, S.; O’Neill, A.; Duesberg, G.C.; Grunlan, J.C.; Moriarty, G.; et al. Large-scale exfoliation of inorganic layered compounds in aqueous surfactant solutions. Adv. Mater. 2011, 23, 3944-3948. [CrossRef] [PubMed]

98. Zhou, L.; Shao, M.F.; Zhang, C.; Zhao, J.W.; He, S.; Rao, D.M.; Wei, M.; Evans, D.G.; Duan, X. Hierarchical CoNi-sulfie nanosheet arrays derived from layered double hydroxides toward effiient hydrazine electrooxidation. Adv. Mater. 2017, 29, 1604080. [CrossRef] [PubMed]

99. Subbaiah, Y.P.V.; Saji, K.J.; Tiwari, A. Atomically thin $\mathrm{MoS}_{2}$ : A versatile nongraphene $2 \mathrm{D}$ material. Adv. Funct. Mater. 2016, 26, 2046-2069. [CrossRef]

100. Zhang, R.K.; Shao, M.F.; Li, Z.H.; Ning, F.Y.; Wei, M.; Evans, D.G.; Duan, X. Photo electrochemical catalysis toward selective anaerobic oxidation of alcohols. Chem. Eur. J. 2017, 23, 8142-8147. [CrossRef] [PubMed]

101. Zhao, Y.F.; Zhang, X.; Jia, X.D.; Waterhouse, G.I.N.; Shi, R.; Zhang, X.R.; Zhan, F.; Tao, Y.; Wu, L.Z.; Tung, C.H.; et al. Sub-3 nm Ultrafine monolayer layered double hydroxide nanosheets for electrochemical water oxidation. Adv. Energy Mater. 2018. [CrossRef]

102. Ma, W.L.; Wang, L.; Xue, J.Y.; Cui, H.T. Ultra-large scale synthesis of Co-Ni layered double hydroxides monolayer nanosheets by a solvent-free bottom-up strategy. J. Alloys Compd. 2016, 662, 315-319. [CrossRef]

103. Hu, G.; Wang, N.; O'Hare, D.; Davis, J. One-step synthesis and AFM imaging of hydrophobic LDH monolayers. Chem. Commun. 2006, 0, 287-289. [CrossRef] [PubMed]

104. Zhao, Y.F.; Li, B.; Wang, Q.; Gao, W.; Wang, C.J.; Wei, M.; Evans, D.G.; Duan, X.; O'Hare, D. NiTi-Layered double hydroxides nanosheets as efficient photocatalysts for oxygen evolution from water using visible light. Chem. Sci. 2014, 5, 951-958. [CrossRef]

105. Ma, R.Z.; Liu, R.P.; Li, L.; Iyia, N.; Sasak, T. Exfoliating layered double hydroxides in formamide: A method to obtain positively charged nanosheets. J. Mater. Chem. 2006, 16, 3809-3813. [CrossRef]

106. Mao, N.; Zhou, C.H.; Tong, D.S.; Yu, W.H.; Lind, C.X.C. Exfoliation of layered double hydroxide solids into functional nanosheets. Appl. Clay Sci. 2017, 144, 60-78. [CrossRef]

107. Yu, J.; Wang, Q.; O'Hare, D.; Sun, L.Y. Preparation of two dimensional layered double hydroxide nanosheets and their applications. Chem. Soc. Rev. 2017, 46, 5950-5974. [CrossRef] [PubMed]

108. Huang, S.; Cen, X.; Peng, H.D.; Guo, S.Z.; Wang, W.Z.; Liu, T.X. Heterogeneous ultrathin films of poly (vinyl alcohol)/layered double hydroxide and montmorillonite nanosheets via layer-by-layer assembly. J. Phys. Chem. B 2009, 46, 15225-15230. [CrossRef] [PubMed]

109. Liu, R.; Wang, Y.Y.; Liu, D.D.; Zou, Y.Q.; Wang, S.Y. Water-plasma-enabled exfoliation of ultrathin layered double hydroxide nanosheets with multivacancies for water oxidation. Adv. Mater. 2017, 29, 1701546. [CrossRef] [PubMed]

110. Zhang, R.K.; Shao, M.F.; Xu, S.M.; Ning, F.Y.; Zhou, L.; Wei, M. Photo-assisted synthesis of zinc-iron layered double hydroxides $/ \mathrm{TiO}_{2}$ nanoarrays toward highly-efficient photoelectrochemical water splitting. Nano Energy 2017, 33, 21-28. [CrossRef] 
111. Zhou, L.; Jiang, S.; Liu, Y.K.; Shao, M.F.; Wei, M.; Duan, X. Ultrathin CoNiP@layered double hydroxides core-shell nanosheets arrays for largely enhanced overall water splitting. ACS Appl. Energy Mater. 2018, 1, 623-631. [CrossRef]

112. Lin, J.H.; Jia, H.N.; Liang, H.Y.; Cheng, S.L.; Cai, Y.F.; Qi, J.L.; Qu, C.Q.; Cao, J.; Fei, W.D.; Feng, J.C. Hierarchical $\mathrm{CuCo}_{2} \mathrm{~S}_{4} @ \mathrm{NiMn}$-layered double hydroxide core-shell hybrid arrays as electrodes for supercapacitors. Chem. Eng. J. 2018, 336, 562-569. [CrossRef]

113. Wang, J.H.; Cui, W.; Liu, Q.; Xing, Z.C.; Asiri, A.M.; Sun, X.P. Recent progress in cobalt-based heterogeneous catalysts for electrochemical water splitting. Adv. Mater. 2016, 28, 215-230. [CrossRef] [PubMed]

114. Chi, H.M.; Qin, B.; Fu, L.; Jia, J.; Yi, B.L.; Shao, Z.G. Vertically aligned FeOOH/NiFe layered double hydroxides electrode. ACS Appl. Mater. Interfaces 2017, 9, 464-471. [CrossRef] [PubMed]

115. Cho, S.; Jang, J.W.; Park, Y.B.; Kim, J.Y.; Magesh, G.; Kim, J.H.; Seol, M.; Yong, K.J.; Lee, K.H.; Lee, J.S. An exceptionally facile method to produce layered double hydroxides on a conducting substrate and their application for solar water splitting without an external bias. Energy Environ. Sci. 2014, 7, 2301-2307. [CrossRef]

116. Yu, C.; Liu, Z.B.; Han, X.T.; Huang, H.W.; Zhao, C.T.; Yang, J.; Qiu, J. NiCo-layered double hydroxides vertically assembled on carbon fiber papers as binder-free high-active electrocatalysts for water oxidation. Carbon 2016, 110, 1-7. [CrossRef]

117. Zhao, M.Q.; Zhang, Q.; Huang, J.Q.; Wei, F. Hierarchical nanocomposites derived from nanocarbons and layered double hydroxides-properties, synthesis, and applications. Adv. Funct. Mater. 2012, 22, 675-694. [CrossRef]

118. Ma, Y.; Wang, Y.C.; Xie, D.H.; Gu, Y.; Zhang, H.M.; Wang, G.Z.; Zhang, Y.X.; Zhao, H.J.; Wong, P.K. $\mathrm{NiFe}$-layered double hydroxide nanosheet arrays supported on carbon cloth for highly sensitive detection of nitrite. ACS Appl. Mater. Interfaces 2018, 10, 6541-6551. [CrossRef] [PubMed]

119. Ning, F.Y.; Shao, M.F.; Zhang, C.L.; Xu, S.M.; Wei, M.; Duan, X. $\mathrm{Co}_{3} \mathrm{O}_{4} @$ layered double hydroxide core/shell hierarchical nanowire arrays for enhanced supercapacitance performance. Nano Energy 2014, 7, 134-142. [CrossRef]

120. Li, X.Y.; Wang, X.; Yuan, X.T.; Dong, W.J.; Huang, F.Q. Rational composition and structural design of in situ grown nickel-based electrocatalysts for efficient water electrolysis. J. Mater. Chem. A 2016, 4, 167-172. [CrossRef]

121. Lu, Z.Y.; Sun, M.; Xu, T.H.; Li, Y.J.; Xu, W.W.; Chang, Z.; Ding, Y.; Sun, X.M.; Jiang, L. Superaerophobic electrodes for direct hydrazine fuel cells. Adv. Mater. 2015, 27, 2361-2366. [CrossRef] [PubMed]

122. Zhang, C.; Shao, M.F.; Zhou, L.; Li, Z.H.; Xiao, K.M.; Wei, M. Hierarchical NiFe layered double hydroxide hollow microspheres with highly-efficient behavior toward oxygen evolution reaction. ACS Appl. Mater. Interfaces 2016, 8, 33697-33703. [CrossRef] [PubMed]

123. Liu, J.P.; Li, Y.Y.; Fan, H.J.; Zhu, Z.H.; Jiang, J.; Ding, R.M.; Hu, Y.Y.; Huang, X.T. Iron oxide-based nanotube arrays derived from sacrificial template-accelerated hydrolysis: Large-area design and reversible lithium storage. Chem. Mater. 2010, 22, 212-217. [CrossRef]

124. Tang, Y.Q.; Fang, X.Y.; Zhang, X.; Fernandes, G.; Yan, Y.; Yan, D.P.; Xiang, X.; He, J. Space-Confined earth-abundant bifunctional electrocatalyst for high-efficiency water splitting. ACS Appl. Mater. Interfaces 2017, 9, 36762-36771. [CrossRef] [PubMed]

125. Yang, Q.; Li, T.; Lu, Z.Y.; Sun, X.M.; Liu, J.F. Hierarchical construction of an ultrathin layered double hydroxide nanoarray for highly-efficient oxygen evolution reaction. Nanoscale 2014, 6, 11789-11794. [CrossRef] [PubMed]

126. Blanchard, P.; Huchet, L.; Lillain, E.; Roncali, J. ation template assisted electrosynthesis of a highly $\pi$-conjugated polythiophene containing oligooxyethylene segments. Electrochem. Commun. 2000, 2, 1-5. [CrossRef]

127. Surendranath, Y.; Dincă, M.; Nocera, D.G. Electrolyte-dependent electrosynthesis and activity of cobalt-based water oxidation catalysts. J. Am. Chem. Soc. 2009, 131, 2615-2620. [CrossRef] [PubMed]

128. Francke, R.; Little, R.D. Three-dimensional hierarchical metal oxide-carbon electrode materials for highly efficient microbial electrosynthesis. Chem. Soc. Rev. 2014, 43, 2492-2521. [CrossRef] [PubMed]

129. Hamid, H.; Shiria, M.; Ehsani, S. Electrosynthesis of neodymium oxide nanorods and its nanocomposite with conjugated conductive polymer as a hybrid electrode material for highly capacitive pseudocapacitors. J. Colloid Interface Sci. 2017, 495, 102-110. 
130. Qiao, X.Y.; Wei, M.C.; Tian, D.; Xia, F.Q.; Chen, P.P.; Zhou, C.L. One-step electrosynthesis of cadmium/aluminum layered double hydroxides composite as electrochemical probe for voltammetric detection of anthracene. J. Electroanal. Chem. 2018, 808, 35-40. [CrossRef]

131. Yamabe, K.; Goto, H. Electrosynthesis of conducting polymers in lecith in liquid crystal reaction field. Fibers Polym. 2018, 19, 248-253. [CrossRef]

132. Shao, M.F.; Li, Z.H.; Zhang, R.K.; Ning, F.Y.; Wei, M.; Evans, D.G.; Duan, X. Hierarchical conducting polymer@clay core-shell arrays for flexible all-solid-state supercapacitor devices. Small 2015, 11, 3530-3538. [CrossRef] [PubMed]

133. Wu, S.X.; Hui, K.S.; Hui, K.N. One-dimensional core-shell architecture composed of silver nanowire@hierarchical nickel-aluminum layered double hydroxide nanosheet as advanced electrode materials for pseudocapacitor. J. Phys. Chem. C 2015, 119, 23358-23365. [CrossRef]

134. Serrà, A.; Gómez, E.; Vallés, E. Novel electrodeposition media to synthesize CoNi-Pt core@shell stable mesoporous nanorods with very high active surface for methanol electro-oxidation. Electrochim. Acta 2015, 174, 630-639. [CrossRef]

135. Yanilkina, V.V.; Nastapovaa, N.V.; Nasretdinovaa, G.R.; Fazleevaa, R.R.; Toropchinaa, A.V.; Osin, Y.N. Methylviologen mediated electrochemical reduction of $\mathrm{AgCl}-\mathrm{A}$ new route to produce a silica core/Ag shell nanocomposite material in solution. Electrochem. Commun. 2015, 59, 60-63. [CrossRef]

136. Li, Z.H.; Shao, M.F.; Zhou, L.; Zhang, R.K.; Zhang, C.; Wei, M.; Evans, D.G.; Duan, X. A flexible all-solid-state micro-supercapacitor based on hierarchical CuO@layered double hydroxide core-shell nanoarrays. Nano Energy 2016, 20, 294-304. [CrossRef]

137. Dong, X.Y.; Wang, L.; Wang, D.; Li, C.; Jin, J. Layer-by-layer engineered Co-Al hydroxide nanosheets/graphene multilayer films as flexible electrode for supercapacitor. Langmuir 2012, 28, 293-298. [CrossRef] [PubMed]

138. Han, J.B.; Lu, J.; Wei, M.; Wang, Z.L.; Duan, X. Heterogeneous ultrathin films fabricated by alternate assembly of exfoliated layered double hydroxides and polyanion. Chem. Commun. 2008, 5188-5190. [CrossRef] [PubMed]

139. Yan, D.P.; Lu, J.; Wei, M.; Han, J.B.; Li, F.; Evans, D.G.; Duan, X. Ordered poly(p-phenylene)/layered double hydroxide ultrathin films with blue luminescence by layer-by-layer assembly. Angew. Chem. 2009, 121, 3119-3122. [CrossRef]

140. Han, J.B.; Xu, X.Y.; Rao, X.Y.; Wei, M.; Evans, D.G.; Duan, X. Layer-by-layer assembly of layered double hydroxide/cobalt phthalocyanine ultrathin film and its application for sensors. J. Mater. Chem. 2011, 21, 2126-2130. [CrossRef]

141. Liang, R.Z.; Tian, R.; Shi, W.Y.; Liu, Z.H.; Yan, D.P.; Wei, M.; Evans, D.G.; Duan, X. Temperature sensor based on CdTe quantum dots-layered double hydroxide ultrathin films via layer-by-layer assembly. Chem. Commun. 2013, 49, 969-971. [CrossRef] [PubMed]

142. Zhang, C.; Zhao, J.W.; Zhou, L.; Li, Z.H.; Shao, M.F.; Wei, M. Layer-by-layer assembly of exfoliated layered double hydroxide nanosheets for enhanced electrochemical oxidation of water. J. Mater. Chem. A 2016, 4, 11516-11523. [CrossRef]

143. Hunter, B.M.; Hieringer, W.; Winkler, J.R.; Gray, H.B.; Muller, A.M. Effect of interlayer anions on [NiFe]-LDH nanosheet water oxidation activity. Energy Environ. Sci. 2016, 9, 1734-1743. [CrossRef]

144. Zhang, J.F.; Liu, J.Y.; Xi, L.F.; Yu, Y.F.; Chen, N.; Sun, S.H.; Wang, W.C.; Lange, K.M.; Zhang, B. Single-atom $\mathrm{Au} / \mathrm{NiFe}$ layered double hydroxide electrocatalyst: Probing the origin of activity for oxygen evolution reaction. J. Am. Chem. Soc. 2018, 140, 3876-3879. [CrossRef] [PubMed]

145. Ahn, H.S.; Bard, A.J. Surface interrogation scanning electrochemical microscopy of $\mathrm{Ni}_{1-\mathrm{x}} \mathrm{Fe}_{\mathrm{x}} \mathrm{OOH}$ $(0<\mathrm{x}<0.27)$ oxygen evolving catalyst: Kinetics of the "fast" iron sites. J. Am. Chem. Soc. 2016, 138, 313-318. [PubMed]

(C) 2018 by the authors. Licensee MDPI, Basel, Switzerland. This article is an open access article distributed under the terms and conditions of the Creative Commons Attribution (CC BY) license (http:/ / creativecommons.org/licenses/by/4.0/). 